\title{
Topological Constraints by the Greenland-Scotland Ridge on AMOC and Climate ${ }^{\mathscr{A}}$
}

\author{
JONATHAN W. RHEINLÆNDER \\ Department of Earth Science, University of Bergen and the Bjerknes Centre for Climate Research, Bergen, Norway \\ DAVID FERREIRA \\ Department of Meteorology, University of Reading, Reading, United Kingdom
}

KERIM H. NISANCIOGLU

Department of Earth Science, University of Bergen and the Bjerknes Centre for Climate Research, Bergen, Norway, and Centre for Earth Evolution and Dynamics, Oslo, Norway

(Manuscript received 26 September 2019, in final form 31 March 2020)

\begin{abstract}
Changes in the geometry of ocean basins have been influential in driving climate change throughout Earth's history. Here, we focus on the emergence of the Greenland-Scotland Ridge (GSR) and its influence on the ocean state, including large-scale circulation, heat transport, water mass properties, and global climate. Using a coupled atmosphere-ocean-sea ice model, we consider the impact of introducing the GSR in an idealized Earth-like geometry, comprising a narrow Atlantic-like basin and a wide Pacific-like basin. Without the GSR, deep-water formation occurs near the North Pole in the Atlantic basin, associated with a deep meridional overturning circulation (MOC). By introducing the GSR, the volume transport across the sill decreases by $64 \%$ and deep convection shifts south of the GSR, dramatically altering the structure of the highlatitude MOC. Due to compensation by the subpolar gyre, the northward ocean heat transport across the GSR only decreases by $\sim 30 \%$. As in the modern Atlantic Ocean, a bidirectional circulation regime is established with warm Atlantic water inflow and a cold dense overflow across the GSR. In sharp contrast to the large changes north of the GSR, the strength of the Atlantic MOC south of the GSR is unaffected. Outside the high latitudes of the Atlantic basin, the surface climate response is surprisingly small, suggesting that the GSR has little impact on global climate. Our results suggest that caution is required when interpreting paleoproxy and ocean records, which may record large local changes, as indicators of basin-scale changes in the overturning circulation and global climate.
\end{abstract}

\section{Introduction}

Changes in the distribution of landmasses driven by continental drift and plate tectonics play a fundamental role in shaping the geometry of ocean basins. The presence of meridional barriers in the ocean has a profound effect on large-scale ocean circulation, localization of deep water formation, and oceanic heat transport that help modulate global energy transports and control

Supplemental information related to this paper is available at the Journals Online website: https://doi.org/10.1175/JCLI-D-190726.s1.

Corresponding author: J. Rheinlænder, jonathan.rheinlender@ uib.no
Earth's energy budget (Toggweiler and Bjornsson 2000; Enderton and Marshall 2009; Ferreira et al. 2010). Changes in ocean basin geometry have been invoked as a key factor in setting the mean climate of Earth, explaining some of the major transitions in global climate over the past 50 million years (Barker and Burrell 1977; Haug and Tiedemann 1998).

Bathymetry (such as oceanic ridges) also influences ocean basin geometry and global ocean circulation. Topographic features can steer major ocean currents, enhance vertical mixing over rough topography (Polzin et al. 1997; De Lavergne et al. 2017), providing a major energy source for driving the meridional overturning circulation, and serve as solid barriers limiting water exchange between adjacent ocean basins (Gille and Smith 2003). Hence, exploring the impacts of changes in 


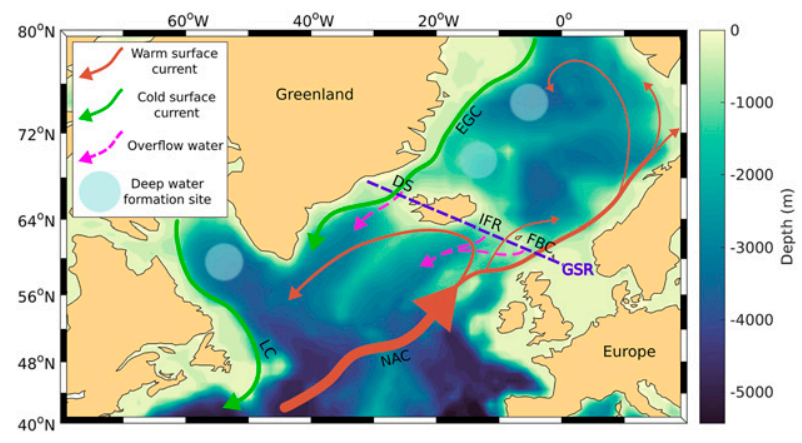

FIG. 1. Bathymetric map of the modern North Atlantic showing the main ocean currents; NAC $=$ North Atlantic Current, EGC = East Greenland Current, and LC = Labrador Current. The dashed magenta line indicates the location of the Greenland-Scotland Ridge (GSR). Circles indicate the approximate location of deepwater formation and dashed violet arrows show the overflow through the Denmark Strait (DS), Faroe Bank Channel (FBC), and Iceland-Faroe Ridge (IFR).

bathymetry on global ocean circulation allows us to separate the effects of bathymetry from changes in, for example, $\mathrm{CO}_{2}$ in driving major climate events (e.g., the glaciation of Antarctica, Drake Passage opening versus declining atmospheric $\mathrm{CO}_{2}$; DeConto and Pollard 2003).

In the North Atlantic region, oceanic gateway changes induced by the emergence of the Greenland-Scotland Ridge (GSR) have been argued to play an important role in the evolution of high-latitude surface climate and North Atlantic Ocean circulation throughout the Cenozoic (the past 65 million years to the present) (Wright and Miller 1996; Stärz et al. 2017). The GSR presents a zonal barrier separating the North Atlantic from the Nordic seas and Arctic Ocean and constricting the exchange of water between these ocean basins (Fig. 1). At present, the main sills of the GSR are less than $500 \mathrm{~m}$ deep, with deeper channels at water depths of $\sim 840 \mathrm{~m}$, where dense waters formed in the Nordic seas can escape. As these cold, dense waters flow over the sill, they mix with warmer, lighter Atlantic water to form North Atlantic Deep Water (NADW) (Hansen and Østerhus 2000), which constitutes the lower branch of the Atlantic meridional overturning circulation (AMOC). Therefore even minor changes in sill depth may significantly impact deep-water exchange and NADW volume transport, potentially causing basinwide changes in circulation (e.g., Roberts and Wood 1997).

Paleo-oceanographic data suggest that variations in the depth of the GSR correlate with major changes in North Atlantic and global climate [see UenzelmannNeben and Gruetzner (2018) for a review]. In particular, during the late Eocene to early Miocene period [35-16 million years ago (Ma)], the GSR gradually deepened, but was interrupted by episodes of topographic uplift, thus impacting the water exchange between the Norwegian Seas and North Atlantic (Wright and Miller 1996; Davies et al. 2001; Via and Thomas 2006). Evidence from $\delta^{13} \mathrm{C}$ records in the deep North Atlantic have suggested that, at times when the GSR was higher, the production of Northern Component Water (NCW; a precursor of the modern NADW) ceased, with limited deep-water exchange across the GSR. As the GSR deepened, it resulted in high NCW fluxes into the deep North Atlantic marking the onset of the modern AMOC. This onset of the interhemispheric northern-sourced circulation cell has also been suggested to play a role in the glaciation of Antarctica at the Eocene-Oligocene transition (EOT), about $33.5 \mathrm{Ma}$, prompting the EOT global cooling (Abelson et al. 2008; Abelson and Erez 2017). However, there is much uncertainty associated with the timing of tectonic gateway changes and their actual impact on AMOC evolution (see Fig. 3 in Ferreira et al. 2018).

It is widely accepted that the presence of the GSR is important for the surface climate conditions and the formation of dense water in the Nordic seas, based on both numerical model simulations and observational data (e.g., Roberts and Wood 1997; Iovino et al. 2008). Meanwhile, its effect on large-scale ocean circulation is not well established. In some models, even modest changes in the sill depth produce large changes in Atlantic overturning circulation, with major consequences for ocean heat transport (OHT) and North Atlantic surface climate (e.g., Roberts and Wood 1997), while in others changes in the sill does not affect AMOC strength (Robinson et al. 2011; Born et al. 2009).

Using a coupled climate model with Miocene boundary conditions ( $\sim 20-15 \mathrm{Ma})$, Stärz et al. (2017) investigated the long-term subsidence history of the GSR. As the GSR deepened, the Arctic Ocean gradually transitioned from a freshwater-dominated environment toward the establishment of a bidirectional flow regime characterizing the modern North AtlanticArctic water exchange. This led to an "Atlantification" of the Nordic seas and Arctic Ocean and increased sea surface temperature (SST) and salinity (SSS) in the high northern latitudes. A similar mechanism has been invoked to explain the observed high-latitude warming of the mid-Pliocene warm period (MPWP; 3.3-3.0 Ma) (Robinson et al. 2011; Hill 2015). Reconstructions of ocean temperature from marine proxy data indicate that, during the MPWP, global mean temperature was warmer by $2^{\circ}-3^{\circ} \mathrm{C}$ compared to modern times (Dowsett et al. 2010), while summer temperatures in the Arctic were about $8^{\circ} \mathrm{C}$ warmer (Brigham-Grette et al. 2013). As a consequence, the North Atlantic equator-to-pole SST gradient was reduced to about $18^{\circ} \mathrm{C}$ (modern is 
$\sim 27^{\circ} \mathrm{C}$ ). The favored hypothesis for the mid-Pliocene warmth is that the AMOC was stronger (inferred from the observed SST pattern), contributing to enhanced meridional heat transport in the North Atlantic Ocean (Dowsett et al. 1992; Raymo et al. 1996; Dowsett et al. 2009). Using a climate model simulation with Pliocene boundary conditions, Robinson et al. (2011) argued that such changes in ocean heat transport could be explained by depth variations in the GSR and showed that lowering the sill by $800 \mathrm{~m}$ leads to a stronger overturning circulation in the subpolar region, increased high-latitude OHT, and higher Arctic SSTs, consistent with the proxy data.

Common for many of these earlier studies (both proxy and model based) is that they assume AMOC strength and poleward ocean heat transport are correlated with the height of the GSR through the production of dense water in the Nordic seas and its control on the overflow strength (Dowsett et al. 1992; Wright and Miller 1996; Raymo et al. 1996; Dowsett et al. 2009; Robinson et al. 2011). There are two main issues with this view. First, from a modern observational point of view there has been no conclusive evidence linking AMOC variability to the formation of Nordic seas overflow water (Hansen and Østerhus 2007; Olsen et al. 2008; Medhaug et al. 2012; Lozier et al. 2017). Rather, AMOC variability is largely attributed to deep water formation south of the GSR in the subpolar North Atlantic (Olsen et al. 2008). Second, it assumes that the OHT across the GSR is nearly completely dominated by the AMOC, which conflicts with a number of studies (e.g., Wunsch 2005; Ferrari and Ferreira 2011; Tett et al. 2014; Årthun et al. 2019) showing a decoupling between northern highlatitude climate and the AMOC at $26^{\circ} \mathrm{N}$. This calls into question the role of the GSR in controlling AMOC strength and high-latitude OHT, in particular on geological time scales, where changes in sill depth are invoked as the primary driver for changes in large-scale ocean circulation and global climate.

In this study, we explore the impact of introducing the GSR in a coupled ocean-atmosphere-sea ice general circulation model (GCM) with idealized land-sea geometry, focusing on the response of the Atlantic overturning circulation. Rather than investigating a specific time in Earth's history, we consider the fundamental role of ocean-basin geometry (induced by changes in bathymetry) in shaping the ocean circulation and mean climate. This builds on previous work by Ferreira et al. (2010). We note, however, that the present study provides valuable insight into understanding Cenozoic climate evolution, where Arctic-Atlantic gateway changes are likely to have played a major role (Stärz et al. 2017; Hutchinson et al. 2019).
In contrast to earlier model studies, we focus on a detailed understanding of how the presence of the GSR influences the location of deep-water formation and its role in shaping the overturning circulation and ocean heat transport. Special attention is paid to the relationship between the AMOC and the northward transport of heat across the GSR and water mass transformation. This allows us to study and review how long-term changes in sill-depth, inferred from proxy records, can impact high-latitude climate as well as global surface climate.

\section{Model and experiment}

We use the coupled atmosphere-ocean-sea ice configuration of the Massachusetts Institute of Technology General Circulation Model (MITgcm) (Marshall et al. 1997) with idealized land-sea geometry, which has been used previously to investigate fundamental aspects of large-scale ocean circulation and its impact on mean climate (e.g., Marshall et al. 2007; Ferreira et al. 2010, 2011; Rose et al. 2013). The model uses the rescaled pressure coordinate $p^{*}$ for the compressible atmosphere and the rescaled height coordinate $z$ for the Boussinesq ocean (Adcroft and Campin 2004). The atmosphere, ocean, and sea ice components are configured on the same cubed-sphere grid at a low-horizontal resolution C32 $(32 \times 32$ points per face $)$, yielding a resolution of roughly $2.8^{\circ}$ at the equator. The cubed-sphere grid allows for better representation of dynamics in high-latitude regions by avoiding problems with the converging meridian at the poles.

The atmospheric model is a five-level primitive equation model of intermediate complexity based on the simplified parameterizations primitive equation dynamics (SPEEDY) scheme (Molteni 2003). This method comprises a four-band radiation scheme, a parameterization of moist convection, diagnostic clouds, and a boundary layer scheme.

The flat-bottomed ocean is $3 \mathrm{~km}$ deep with 30 vertical levels, increasing from $10 \mathrm{~m}$ in the surface layers to $200 \mathrm{~m}$ in the deep ocean. Effects of mesoscale eddies are parameterized as an advective process (Gent and McWilliams 1990) and isopycnal diffusion (Redi 1982), both with a transfer coefficient of $1200 \mathrm{~m}^{2} \mathrm{~s}^{-1}$. For the vertical mixing the nonlocal $K$-profile parameterization (KPP) scheme (Large et al. 1994) is used, which deals with the different mixing processes in the ocean interior and surface boundary layer.

The sea ice model is a two-and-a-half-layer thermodynamic model based on Winton (2000) with prognostics variables including sea ice area, snow and ice thickness, brine pockets, and sea ice salinity. There is no 

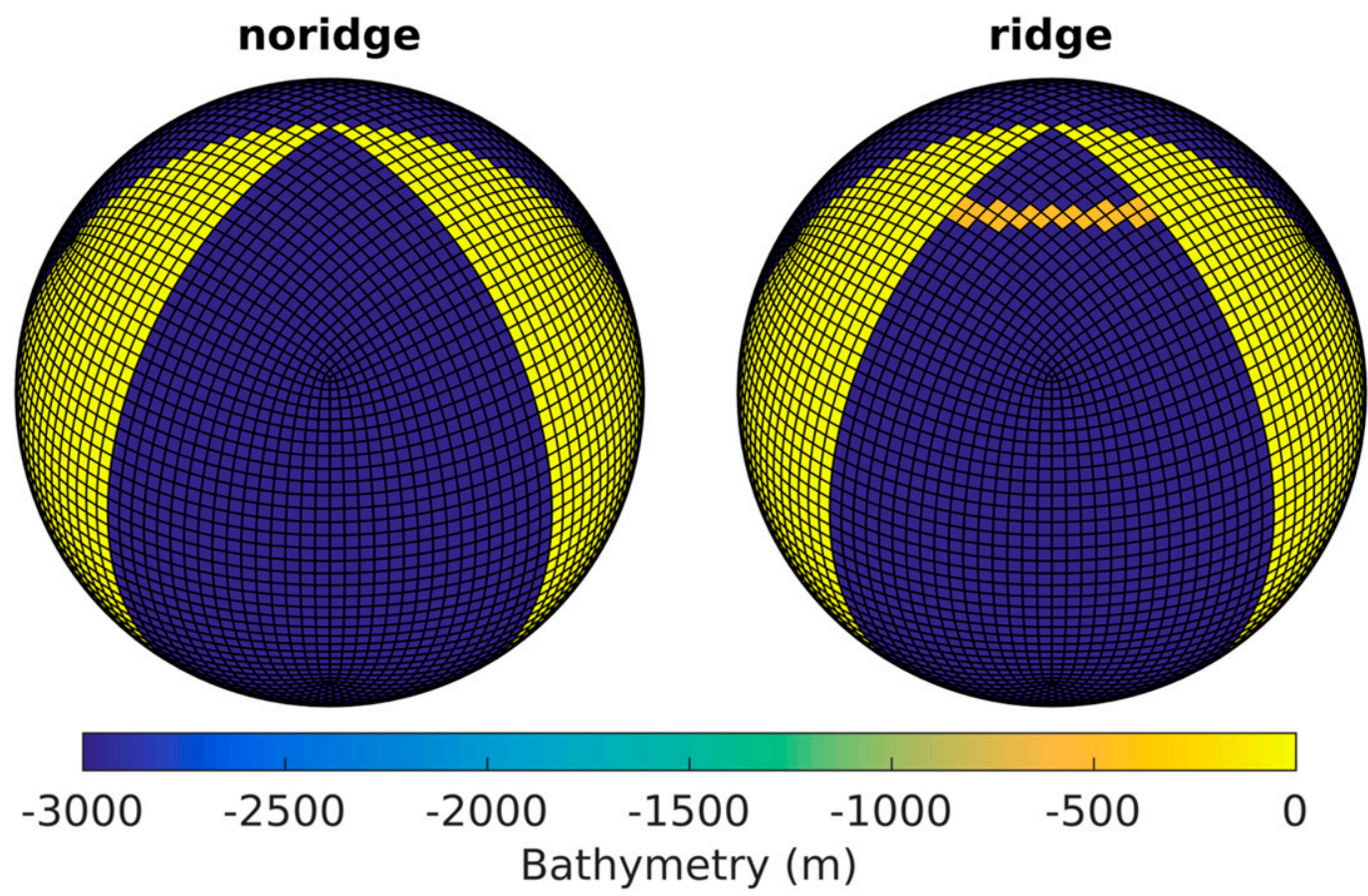

FIG. 2. Land-sea distribution and bathymetry (m) for the noridge and ridge configurations.

ice dynamics, but sea ice deformation is crudely represented by a horizontal thickness diffusivity of $2000 \mathrm{~m}^{2} \mathrm{~s}^{-1}$.

The land model is a simple two-layer model with prognostic temperature, liquid groundwater, and snow height. Precipitation that falls on land (as snow or rain) is evenly distributed along the coast as runoff. There is no orographic effect from landmasses and no continental ice. Land albedo is set to 0.10 , plus a contribution from snow, if present, which varies from 0.25 to 0.80 depending on snow height, surface temperature, and snow age. Orbital forcing and $\mathrm{CO}_{2}$ levels are at presentday values.

\section{Description of experiments}

To test the impact of the Greenland-Scotland Ridge on ocean circulation and climate, two bathymetric configurations of the model are considered. These are illustrated in Fig. 2. The reference configuration (noridge) comprises two $45^{\circ}$ wide strips of land, set $90^{\circ}$ apart, extending from the North Pole to $40^{\circ} \mathrm{S}$ and separates the ocean into a small "Atlantic-like" and a large "Pacificlike" basin, with a zonally unbound Southern Ocean. For simplicity we refer to these as the Atlantic and Pacific basin respectively. The second configuration (ridge) is similar to noridge, with the only difference that an oceanic ridge, extending across the small basin between $61^{\circ}$ and $65^{\circ} \mathrm{N}$, is introduced. The ridge has a uniform sill-depth of $500 \mathrm{~m}$, roughly corresponding to the average depth of the modern GSR. Thereby, the ridge configuration mimics the effect of the GSR, by separating the Atlantic basin into a semienclosed (polar) basin at high latitudes, representing the Nordic seas and Arctic Ocean, and a larger basin representing the subtropical and subpolar Atlantic. In contrast, noridge presents an Atlantic Ocean without zonal boundaries (i.e., ridges).

Despite the simplified geometry, the model captures the general features associated with the large-scale ocean circulation in the subpolar and high-latitude Atlantic: shallow wind-driven gyres at midlatitudes, a surface current resembling the North Atlantic Current (NAC) transporting warm and saline water from the subtropics to the polar regions, and deep-water formation at northern high latitudes (Figs. 6 and 9). It also reproduces a key asymmetry between the two basins: deep water formation in the small basin drives a strong and deep meridional overturning circulation (i.e., an AMOC), while deep water formation is absent in the large basin (see also Ferreira et al. 2010).

The noridge was initialized with global temperature and salinity fields from the "Double-Drake" simulation in Ferreira et al. (2010) and integrated forward until reaching a steady-state solution after 4000 years. The initial conditions for ridge were obtained by adding the GSR to the noridge simulation and then run for 4000 years, allowing the ocean state to adjust to the altered bathymetry. This is sufficient time for both surface and deep waters to equilibrate. Note that the local ocean 

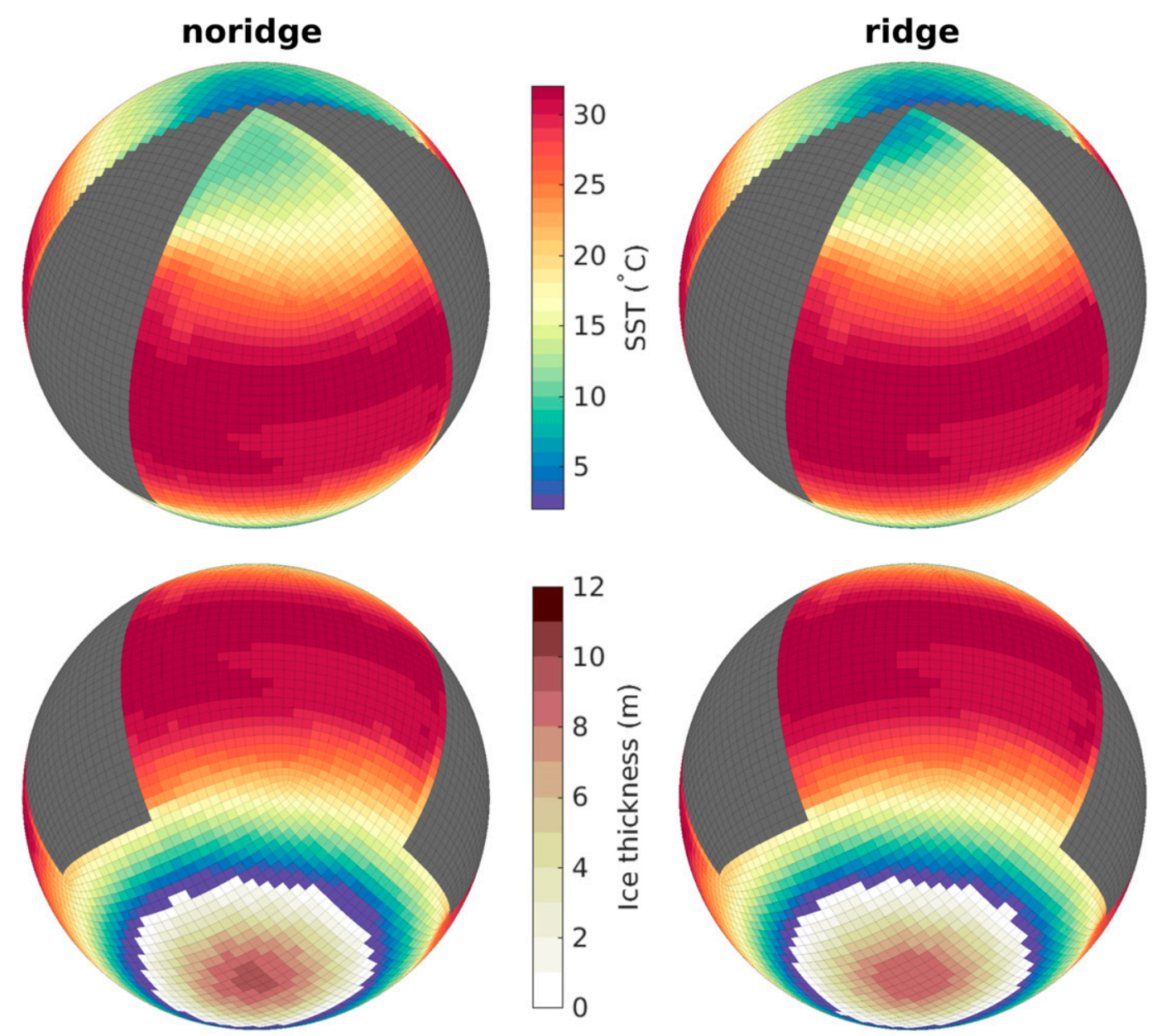

FIG. 3. Annual mean sea surface temperature (SST; ${ }^{\circ} \mathrm{C}$ ) and sea ice thickness (in m) over the small basin for the (left) noridge and (right) ridge experiments. Values are based on the final 100 years at the end of the integration.

adjustment to the GSR is relatively fast (within the first 200 years). In the following, we compare the last 100 years of the ridge experiment to the last 100 years of the noridge solution.

\section{Results}

\section{a. Mean climate without the Greenland-Scotland ridge (noridge)}

The mean climate of noridge is depicted in Fig. 3 (left) showing the annual mean SST and sea ice thickness. The equilibrium solution of noridge is warm with a global mean SST of $20.7^{\circ} \mathrm{C}$ (Table 1) and a relatively weak equator-to-pole SST gradient of only $19.0^{\circ} \mathrm{C}$ (in the Atlantic basin) owing to the strong northward heat transport associated with the MOC. Consequently, the northern high latitudes are completely ice-free. In addition, there is an east-west asymmetry in high-latitude SST and SSS, with warmer and saltier surface waters on the eastern side of the basin, associated with the northward warm boundary current (analogous to the North Atlantic Drift), and extension of colder and fresher waters on the western side and in the interior of the basin. In the Southern Hemisphere, a strong zonal current driven by the intense westerly winds suppresses poleward ocean heat transport (i.e., the Drake Passage effect; Toggweiler and Samuels 1995) allowing a large and thick $(\sim 10 \mathrm{~m})$ ice cap to form. We note that the surface climate of noridge has many similarities to the climate of the MPWP, where Arctic sea ice cover was dramatically reduced, or absent, and the North AtlanticArctic SST gradient was reduced to $\sim 18^{\circ} \mathrm{C}$ (Dowsett et al. 2010). Therefore, the MPWP is often used as an analog for a future warming scenario.

In Fig. 4 we show the residual-mean overturning circulation integrated over the Atlantic basin (i.e., the total meridional volume transport defined as the sum of the Eulerian meridional velocity) and the eddy-induced 
TABLE 1. Climate variables for noridge and ridge experiments. Mean SST $\left({ }^{\circ} \mathrm{C}\right)$ and SSS (psu) in the polar basin averaged north of $70^{\circ} \mathrm{N}$. $\mathrm{AMOC}_{\max }(\mathrm{Sv})$ is calculated as the maximum overturning streamfunction at $26^{\circ} \mathrm{N}$ below $500-\mathrm{m}$ depth in the Atlantic basin; $\Psi_{O, 70 \mathrm{~N}}$ and $\Psi_{B, 70 \mathrm{~N}}$ are the maximum volume transport by the meridional overturning and barotropic streamfunction, respectively, across the GSR; $\mathrm{OHT}_{70 \mathrm{~N}}$ is the meridional northward OHT in petawatts $\left(1 \mathrm{PW}=10^{15} \mathrm{~W}\right)$ across $70^{\circ} \mathrm{N}$ in the Atlantic basin.

\begin{tabular}{lccccrrr}
\hline \hline Expt & $\begin{array}{c}\text { Global mean } \\
\mathrm{SST}\left({ }^{\circ} \mathrm{C}\right)\end{array}$ & $\begin{array}{c}\text { Mean SST polar } \\
\text { basin }\left({ }^{\circ} \mathrm{C}\right)\end{array}$ & $\begin{array}{c}\text { Mean SSS polar } \\
\text { basin }(\mathrm{psu})\end{array}$ & $\begin{array}{c}\text { Max } \\
\text { AMOC }(\mathrm{Sv})\end{array}$ & $\begin{array}{c}\Psi_{O, 70 \mathrm{~N}} \\
(\mathrm{~Sv})\end{array}$ & $\begin{array}{c}\Psi_{B, 70 \mathrm{~N}} \\
(\mathrm{~Sv})\end{array}$ & $\begin{array}{c}\mathrm{OHT}_{70 \mathrm{~N}} \\
(\mathrm{PW})\end{array}$ \\
\hline Noridge & 20.7 & 11.5 & 34.55 & 23.2 & 16.0 & $<5$ & 0.22 \\
Ridge & 20.8 & 10.3 & 34.48 & 22.1 & 5.7 & 8.0 & 0.15 \\
\hline
\end{tabular}

velocity parameterized with the Gent-McWilliams scheme. In the upper ocean $(0-500 \mathrm{~m})$, the circulation is dominated by shallow overturning cells, whose horizontal structure is related to the wind-driven circulation in the subtropical and subpolar gyres. The deep overturning circulation is characterized by a clockwise circulation, associated with deep water formation in the northern high latitudes, extending from below the wind-driven layer to the abyssal ocean. In the absence of a zonal barrier in the Atlantic basin, the MOC stretches to the North Pole, where surface water cools and sinks, returning southward in the deep overturning branch with a maximum of $23.2 \mathrm{~Sv}$ $\left(1 \mathrm{~Sv} \equiv 10^{6} \mathrm{~m}^{3} \mathrm{~s}^{-1}\right)$ at $26^{\circ} \mathrm{N}$. We note the absence of an abyssal overturning cell associated with Antarctic Bottom Water $(\mathrm{AABW})$ formation. This is due to insufficient brine release in the Southern Ocean possibly related to the absence of an Antarctic continent. As a consequence, the overturning circulation in the Atlantic basin is dominated by deep water formation in the North Atlantic.

The meridional ocean heat transport in the Atlantic basin, shown in Fig. 5, is northward everywhere in the basin, with a cross-equatorial transport of $0.7 \mathrm{PW}$, which can be attributed to the MOC transporting warm water north and returning cold water at depth. The Atlantic OHT peaks at about $20^{\circ} \mathrm{N}$ with a maximum of $1.18 \mathrm{PW}$, to be compared to the observed $\sim 1.2 \mathrm{PW}$ (Trenberth and Caron 2001), and is associated with a "mixed" circulation spanning both the shallow Ekman-driven subtropical cell and the deep overturning cell (Ferrari and Ferreira 2011). We also notice a relatively large interdecadal variability (shading) in the subtropical OHT, which is due to stronger variability in the MOC at these latitudes (not shown). At subpolar and high northern latitudes, the OHT is dominated by the strong MOC transporting roughly $16 \mathrm{~Sv}$ across $70^{\circ} \mathrm{N}$ (just north of the GSR) corresponding to a heat transport of $0.22 \mathrm{PW}$ (Table 1) maintaining the northern high latitudes warm and ice free. By comparison, the observed modern transport across the GSR is only about $8.5 \mathrm{~Sv}$ (Østerhus et al. 2005).

\section{b. Effect of the GSR on meridional overturning circulation}

When the GSR is introduced, the transport of warm and salty Atlantic water over the GSR by the MOC is
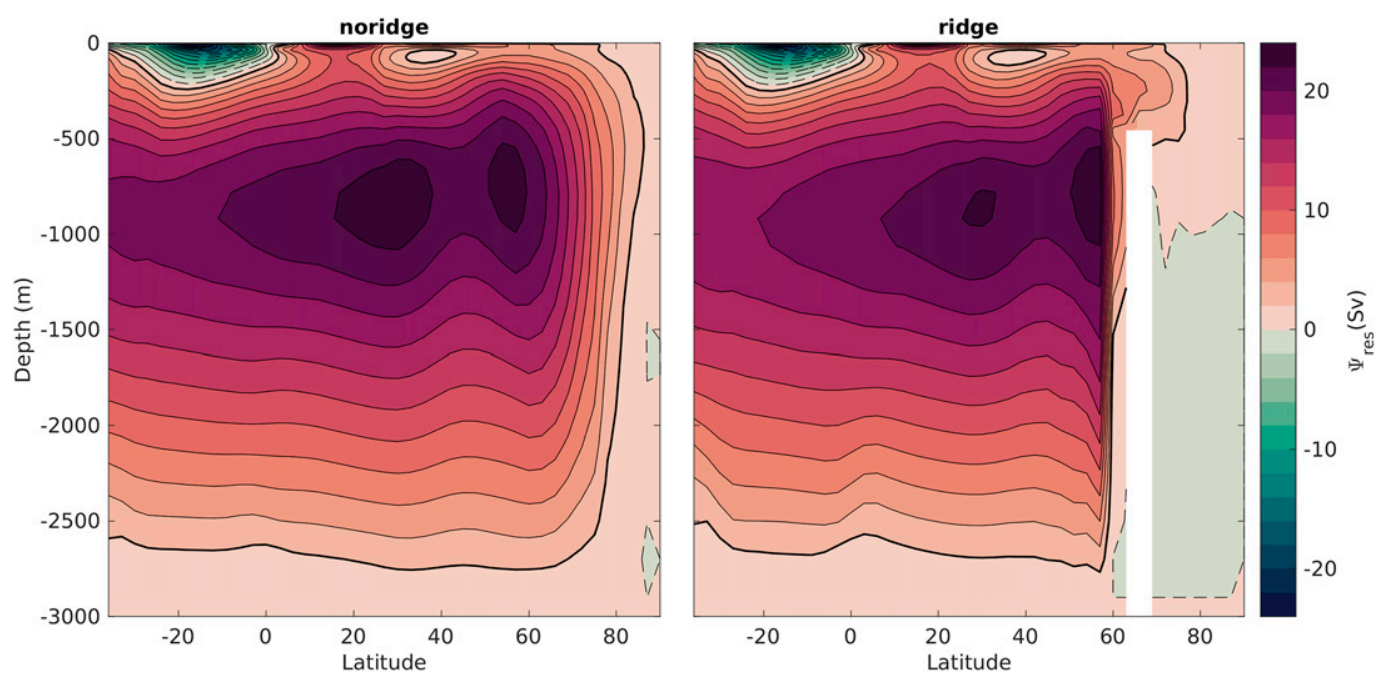

FIG. 4. Residual meridional overturning circulation $\left(\mathrm{MOC}_{z}\right)$ in Sverdrups $\left(1 \mathrm{~Sv}=10^{6} \mathrm{~m}^{3} \mathrm{~s}^{-1}\right)$ averaged over the Atlantic basin for (left) noridge and (right) ridge. Contour lines are plotted at 2-Sv intervals, with solid (dashed) lines corresponding to clockwise (counterclockwise) circulation and the zero contour indicated by the thick black line. 


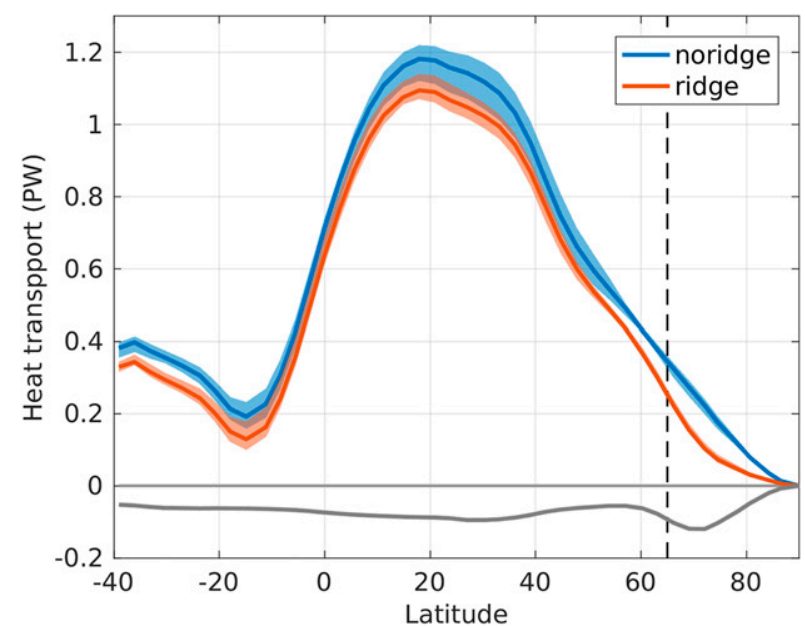

FIG. 5. Zonal mean northward ocean heat transport (in PW) over the Atlantic basin for the noridge (blue) and ridge (red) experiments, and the difference between the two (gray). Shading shows the interdecadal spread in OHT for each experiment, calculated as the difference between the maximum and minimum value over the last 100 years. The approximate location of the GSR is shown by the black dashed line.

reduced by $64 \%$ (from 16 to $5.7 \mathrm{~Sv}$ at $70^{\circ} \mathrm{N}$ ). As a consequence, the spatial structure of the MOC changes dramatically, but mostly at subpolar and high latitudes (Fig. 4, right). The downwelling branch of the deep overturning cell shifts southward, and the streamfunction decays sharply immediately to the south of the GSR. A small overturning circulation remains north of the ridge, associated with a dense overflow from the polar basin, balanced by a warm inflow at the surface. Despite significant changes in the structure of the overturning at high latitudes, the MOC south of $60^{\circ} \mathrm{N}$ is generally not affected; the volume transport at $26^{\circ} \mathrm{N}$ decreases from 23.2 to $22.1 \mathrm{~Sv}$ (i.e., a $5 \%$ reduction). This suggests that the net deep water production in the North Atlantic and high latitudes remains unchanged, while the main difference between noridge and ridge is in the localization of deep-water formation and MOC structure.

The impact of the GSR on the horizontal circulation is illustrated in Fig. 6b, showing the barotropic streamfunction featuring a basinwide anticyclonic gyre in the subtropics (STG), a cyclonic subpolar gyre (SPG) at subarctic latitudes (between $40^{\circ}$ and $70^{\circ} \mathrm{N}$ ), and an anticyclonic gyre at high latitudes driven by the polar easterlies north of $57^{\circ} \mathrm{N}$. For noridge the wind-forced barotropic volume transport at the GSR latitudes is relatively small (less than $5 \mathrm{~Sv}$ ), indicating that the total transport is dominated by the MOC (Table 1). In ridge, however, the barotropic flow intensifies associated with a poleward expansion of the SPG. Note that there are no major changes in zonal wind stress (i.e., Fig. 6a), which implies that the changes in the barotropic streamfunction are a direct consequence of the topography changes. As a result, the barotropic component of the volume transport over the GSR increases (from $<5$ to $\sim 8 \mathrm{~Sv}$ ), while the transport by the MOC decreases (Fig. 4). Hence, there is a partial conversion of the flow from an overturning to a barotropic flow with the introduction of the GSR. Nonetheless, the net (barotropic + MOC) volume transport over the GSR decreases as the MOC weakens and so does the OHT.

To better understand the changes in the gyre circulation, horizontal velocities averaged over the top $100 \mathrm{~m}$ for the North Atlantic are shown in Figs. 6c and $6 \mathrm{~d}$. In both cases, the surface flow in the polar basin is dominated by a warm cyclonic boundary current entering at the eastern side of the basin. Because of the zonal barrier in ridge, however, a substantial part of the poleward flow is steered along the GSR following constant $f / H$ contours (where $f$ is the Coriolis parameter and $H$ is the depth), seen as an enhanced westward barotropic flow (at the GSR latitudes). This is consistent with observations and models showing that a substantial part of the NAC is steered by the complex bottom topography and recirculates south of the GSR (Bower et al. 2019; Stärz et al. 2017).

\section{c. Hydrographic changes in the North Atlantic}

As suggested by the MOC response, the GSR also affects the distribution of water mass properties (i.e., potential temperature and salinity) in the northern Atlantic basin. A cooling and freshening $\left(3^{\circ}-6^{\circ} \mathrm{C}\right.$ and 0.1-0.7 psu respectively) is simulated over most of the water column north of the GSR, as the shallow sill weakens the flow of warm, salty subtropical waters (Fig. 7). As a result, the polar basin becomes more stratified, notably because a strong polar halocline can develop. However, the polar basin remains too warm for sea ice to form. South of the GSR, the surface water becomes warmer and saltier, as a result of the changes in the barotropic circulation shown above (Fig. 6b). In addition, a small increase in temperature and salinity $\left(\sim 1^{\circ} \mathrm{C}\right.$ and $\left.\sim 0.1 \mathrm{psu}\right)$ can be seen at middepth in the subtropical Atlantic associated with changes in the properties of the NADW.

Because of the high-latitude cooling, the density increases dramatically north of the GSR, while it decreases slightly south of the GSR, resulting in an upward sloping of isopycnals from south to north (Fig. 7; bottom row). This is due to the fact that stratification is dominated by temperature in this warm state. In a colder 


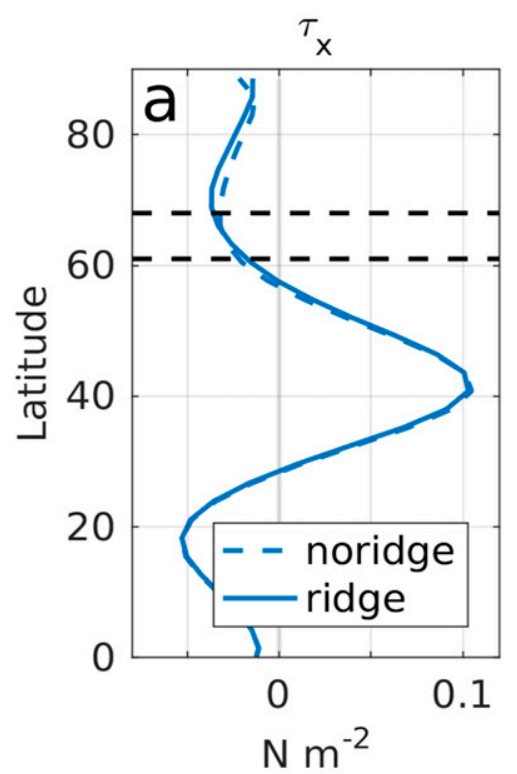

Barotropic streamfunction
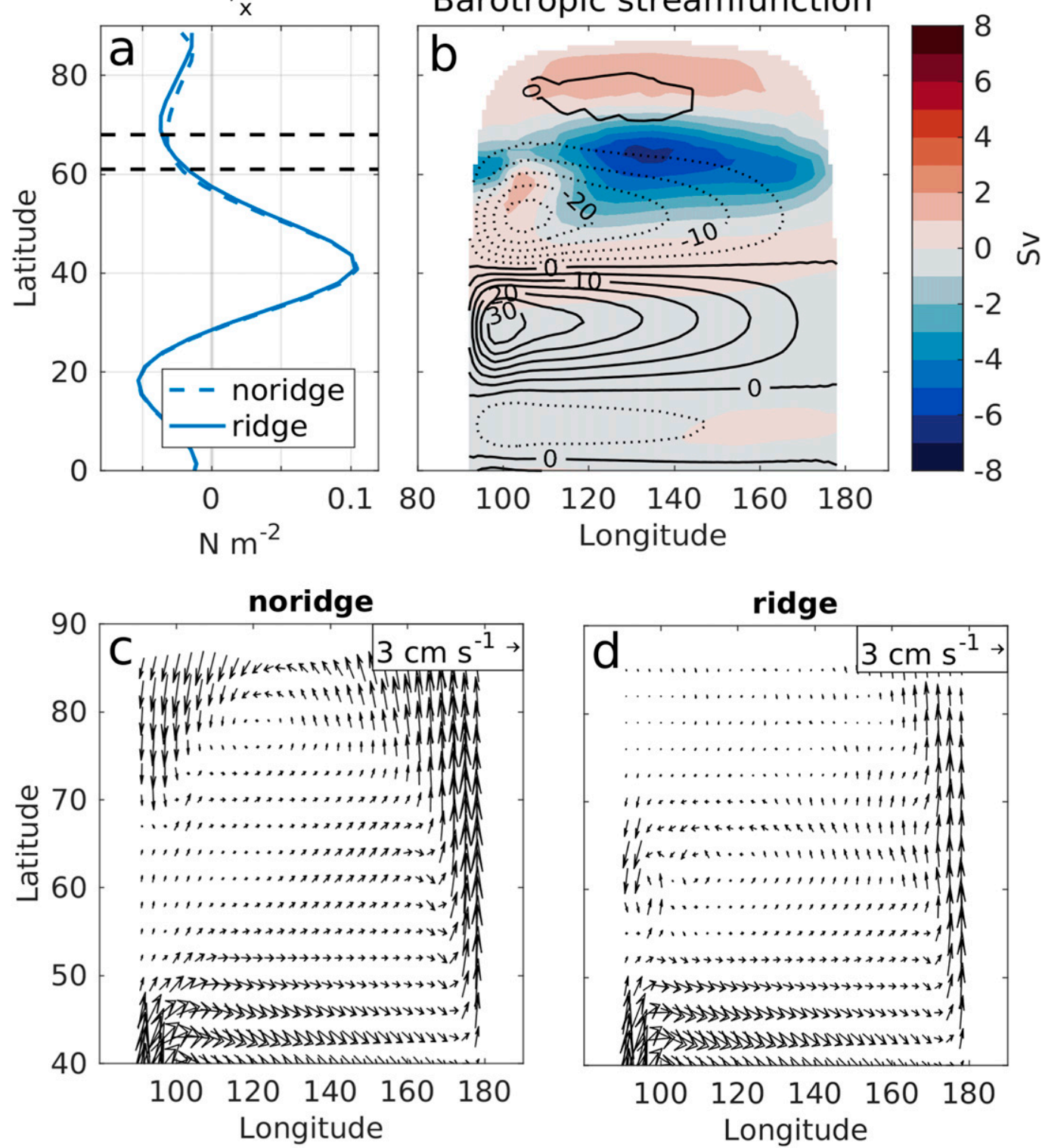

ridge

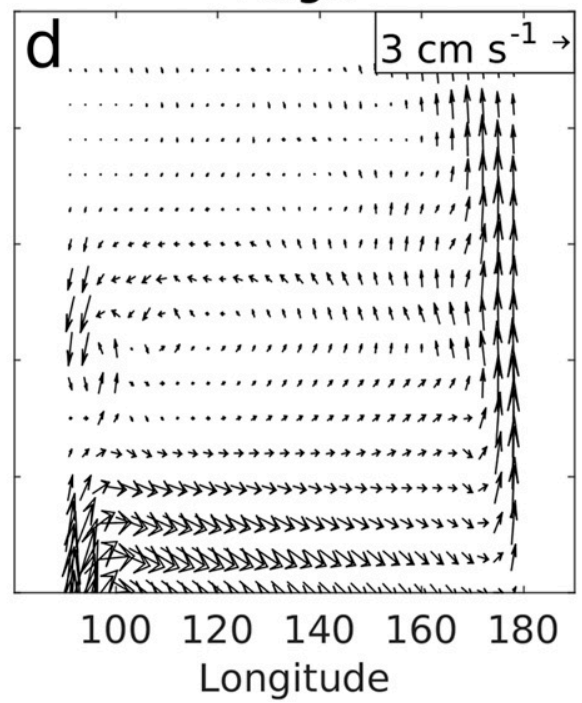

FIG. 6. Wind stress and horizontal circulation in the Atlantic basin. (a) Zonal mean wind stress $\left(\tau_{x} ; \mathrm{N} \mathrm{m}^{-2}\right)$ for noridge (dashed) and ridge (solid). The approximate position of the GSR is indicated by the black dashed lines. (b) Barotropic streamfunction (Sv) for noridge shown in contours with 5-Sv contour intervals where positive (negative) values correspond to clockwise (counterclockwise) circulation. Shading shows the barotropic streamfunction anomaly calculated as the difference between ridge and noridge. (c),(d) Mean top 100-m horizontal velocities in $\mathrm{cm} \mathrm{s}^{-1}$ for noridge and ridge, respectively.

climate, with a small thermal expansion coefficient, density might decrease from the freshening. The density structure reveals a modern-like bidirectional circulation regime with Atlantic water inflow in the surface to subsurface and a dense $\left(\sigma_{\theta}>27.6\right)$ southward outflow above the sill. Here, the enhanced density contrast across the GSR help drive the overflow, which in turn is balanced by the inflow (Hansen and Østerhus 2000). Hence, by introducing the GSR, the polar basin is transformed into a reservoir of dense and less ventilated deep water with longer residence time due to limited exchange with the North Atlantic.

\section{d. Ocean heat transport changes}

The changes in the North Atlantic Ocean circulation are also reflected in the meridional OHT. Northward OHT decreases throughout the Atlantic basin (Fig. 5) when introducing the ridge. South of the GSR the 

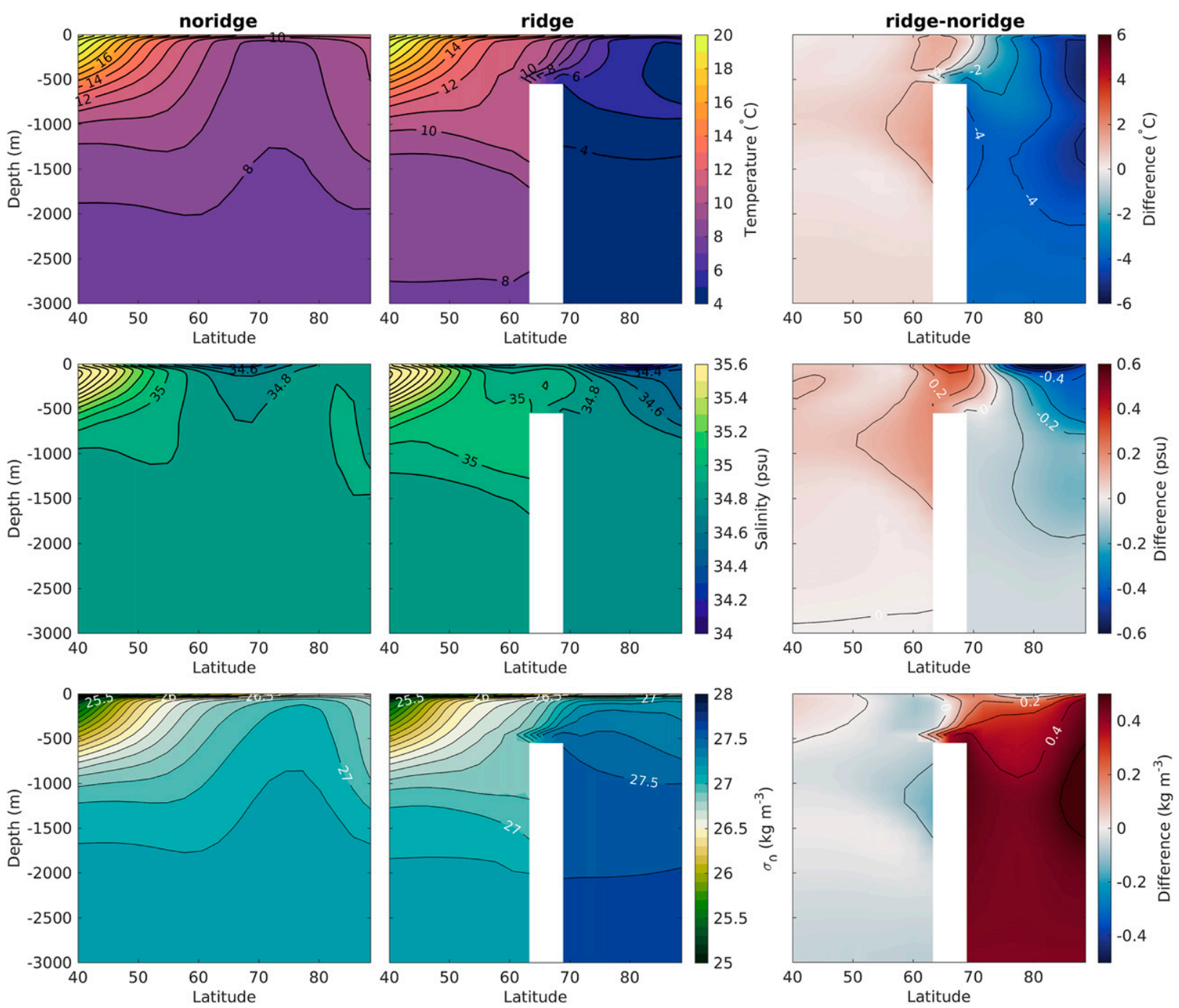

FIG. 7. (top) Zonal mean potential temperature $\left({ }^{\circ} \mathrm{C}\right)$, (middle) salinity (psu), and (bottom) potential density referenced to the surface $\left(\sigma_{0}\right.$; $\mathrm{kg} \mathrm{m}^{-3}$ ) in the North Atlantic for (left) noridge and (middle) ridge, and (right) the difference between the two (i.e., ridge - noridge).

reduction in OHT (by $0.08 \mathrm{PW}(7 \%)$ at $\left.20^{\circ} \mathrm{N}\right)$ is consistent with the small weakening $(\sim 5 \%)$ of the deep MOC (Fig. 4). The most prominent differences in OHT occur in the subpolar and high latitude regions, where the changes in the MOC are largest. However, despite the weak MOC in this region, the OHT across the GSR only decreases by $32 \%$ (from $0.22 \mathrm{PW}$ to $0.15 \mathrm{PW}$ at $70^{\circ} \mathrm{N}$ ), which implies a disconnect between changes in the MOC and high-latitude OHT. We note that there are no compensating effects by the atmospheric heat transport. Further north, the poleward OHT decays rapidly because less warm Atlantic water reaches the high latitudes.

To help understand the changes in OHT between the two states, we consider the scaling argument by Ferrari and Ferreira (2011), which states that the heat transport associated with a closed circulation scales as $\sim \rho_{0} c_{p} \Psi \Delta_{z} \theta$, where $\Psi$ is the strength of the overturning circulation and $\Delta_{z} \theta$ the vertical temperature gradient it encounters. Also, $\rho_{0}$ is a reference density and $c_{p}$ is the heat capacity of seawater. In the absence of a zonal barrier (noridge), the volume transport across $70^{\circ} \mathrm{N}$ is high $(\Psi=16 \mathrm{~Sv}$; Table 1$)$, and the MOC spans the entire water column with a temperature gradient of about $4^{\circ} \mathrm{C}$. The scaling yields a poleward OHT of roughly $0.26 \mathrm{PW}$, slightly more than the actual OHT in Fig. 5. In this case, the poleward heat transport is dominated by the deep MOC. For ridge, $\Psi$ is only $5.7 \mathrm{~Sv}$ (over the GSR), but is compensated by a larger temperature contrast of almost $8^{\circ} \mathrm{C}$ between the surface inflow and the deep outflow over the sill (Fig. 7). Thus the scaling gives an OHT of $0.18 \mathrm{PW}$, close to the simulated $0.15 \mathrm{PW}$. The larger 
temperature contrast is a result of the stronger gyre circulation (Fig. 6b) providing warmer water at the surface, while the outflow is colder, thereby facilitating a more efficient heat transport. Hence, the presence of the GSR completely changes the dynamics of the North Atlantic-Arctic circulation; as the deep MOC vanishes poleward of $50^{\circ} \mathrm{N}$, the heat transport across the GSR is dominated by a shallow circulation (driven by a combination of surface winds and buoyancy forcing). This is consistent with earlier model studies suggesting that the SPG accounts for most of the OHT across the GSR in the modern day climate (Spall 2001; Born et al. 2009; Ferrari and Ferreira 2011; Li and Born 2019).

\section{e. High-latitude and global surface climate response}

The GSR has a large impact on the surface climate conditions in the North Atlantic region through the aforementioned ocean circulation changes (Fig. 3, right, and Fig. 7). The high-latitude surface ocean cools and freshens by $2^{\circ}-4^{\circ} \mathrm{C}$ and $1-2$ psu respectively, with the largest changes occurring on the western side of the polar basin. The average SST in the polar basin decreases to $10.3^{\circ} \mathrm{C}$ (Table 1 ), and the Atlantic equator-topole SST gradient increases to $22.8^{\circ} \mathrm{C}$ (compared to $19.0^{\circ} \mathrm{C}$ in noridge). This is consistent with proxy data and previous model simulations (e.g., Robinson et al. 2011; Stärz et al. 2017), suggesting that shallow sill depths produce lower Arctic surface temperatures and greater North Atlantic temperature gradients. Meanwhile, the polar basin remains too warm for sea ice to form. The effect on global surface climate, however, is small, as illustrated by Fig. 8, showing the global surface air temperature (SAT) difference between ridge and noridge. While the presence of the GSR has a strong local effect at northern high latitudes, the surface climate outside the polar basin does not change much. We note, however, a small warming over the Southern Ocean and reduced sea ice thickness (Fig. 3b), which is likely due to the weakening of the AMOC and northward OHT (Fig. 5). Ultimately, the simulated changes in SAT are linked to the spatial pattern of the OHT changes (Fig. 5). At low latitudes the uniform shift in the transport profile results in the same heat flux convergence and hence same flux to the atmosphere. Consequently, there is no change in surface air temperature. In contrast, the surface climate changes at subpolar and high latitudes are attributed to a southward shift in the location of OHT convergence. The fact that surface climate response is confined to the northern high latitudes is conflicting with earlier proxybased studies which suggest that deepening of the GSR triggered global cooling at the EOT (e.g., Abelson et al. 2008; Abelson and Erez 2017).

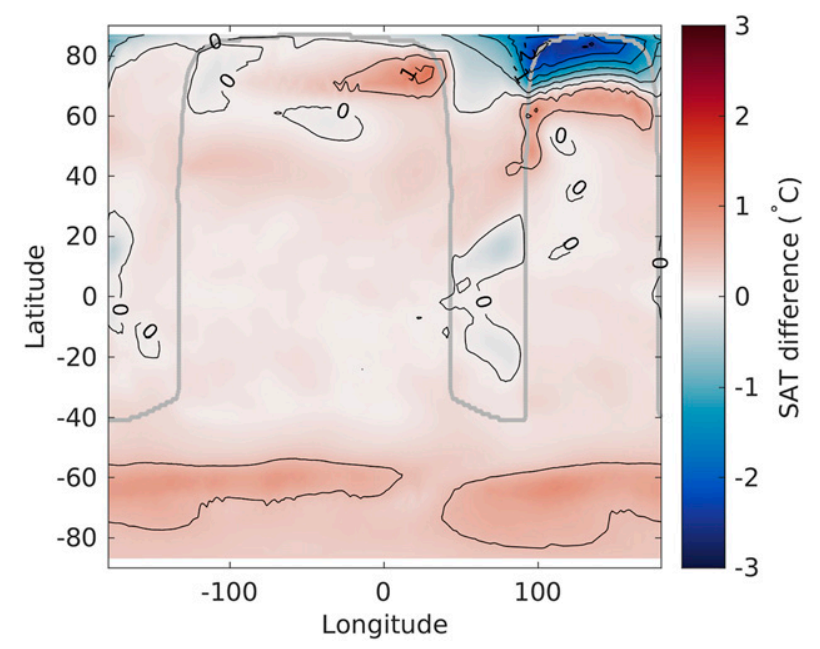

FIG. 8. Global annual mean surface air temperature anomaly (SAT; ${ }^{\circ} \mathrm{C}$ ) calculated as the difference between the final 100 years of ridge and noridge. Contour lines are plotted at $0.5^{\circ} \mathrm{C}$ intervals.

In the present climate, it is widely accepted that variations in air-sea fluxes over the subpolar North Atlantic have a significant effect on AMOC strength (e.g., Lozier et al. 2017; Sévellec et al. 2017). To better understand the link between the simulated changes in high-latitude surface climate and the MOC, we compare the surface density fluxes (Fig. 10) to the mixed layer depth (Fig. 9) reflecting the location of deep convection. Overall, there is a net buoyancy loss (i.e., densification) over the North Atlantic dominated by ocean heat loss, while the freshwater fluxes, mainly associated with $E-P$ and runoff along the boundaries (in the absence of sea ice), contribute only with a small buoyancy gain. In noridge deeper mixed layers are found in the northwestern part of the basin, where there is strong ocean heat loss. As the Atlantic inflow weakens in ridge, the surface water gets colder and the ocean-atmosphere heat flux is reduced poleward of $70^{\circ} \mathrm{N}$ (Fig. 10). At the same time, the imprint of the freshwater forcing, by precipitation and runoff, is more pronounced, although its effect on surface density is small compared to the changes in heat flux. The reduced buoyancy loss weakens deep convection in the polar basin, also illustrated by the shallower mixed layers in Fig. 9. This results in poorly ventilated deep waters below the sill depth. Meanwhile, deep convection is enhanced south of the GSR as indicated by the increased buoyancy loss between $60^{\circ}$ and $70^{\circ} \mathrm{N}$, which is uniquely attributed to warmer SSTs along the GSR that favors stronger ocean-atmosphere heat fluxes and deeper mixed layers. Hence, when the GSR is present, deep convection occurs both in the polar basin (albeit weaker) and the subpolar North Atlantic. A similar response was found in a recent modeling study, 

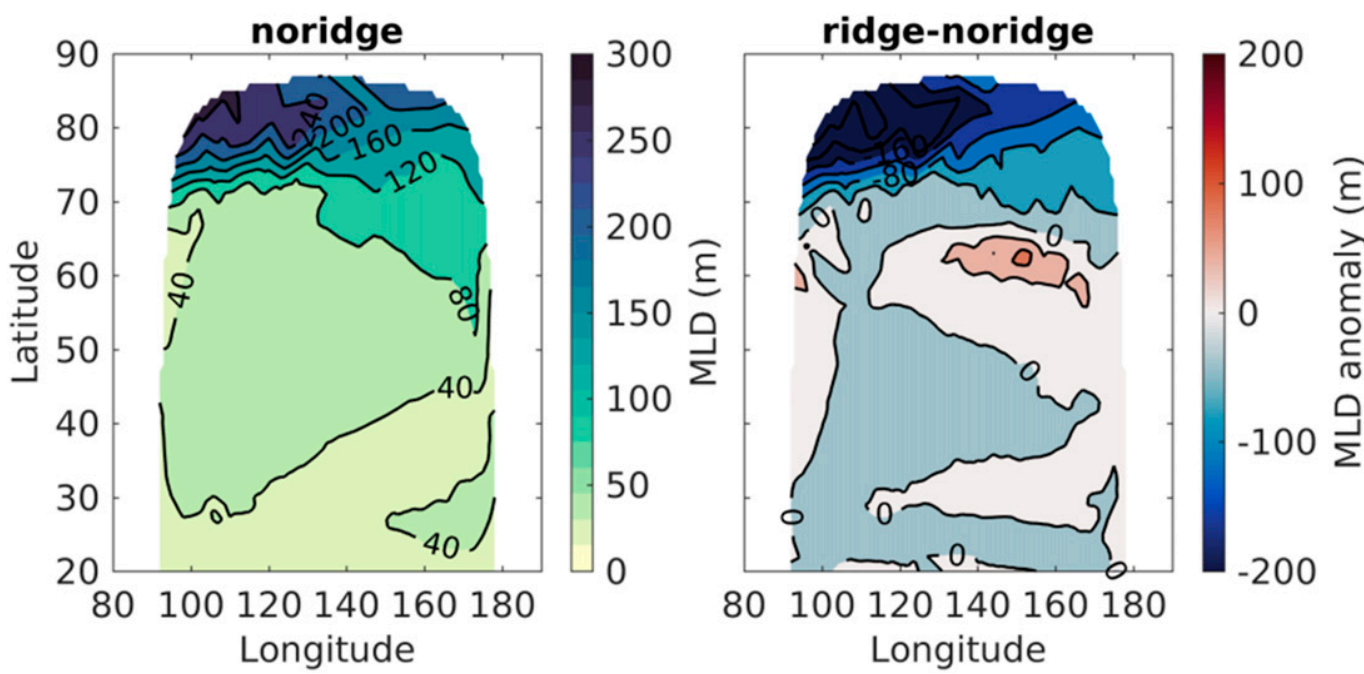

FIG. 9. Annual-mean mixed layer depth (MLD; m) in the northern Atlantic, showing (left) absolute values for noridge and (right) anomalies of ridge relative to noridge.

using late Eocene boundary conditions (Hutchinson et al. 2019), demonstrating that deep water formation shifted to the south of the GSR in response to a shoaling of the sill from 500 to $25 \mathrm{~m}$. They also suggest that the Arctic-Atlantic freshwater transport may be critical in determining the location of deep-water formation, including the preferred basin of sinking (i.e., Atlantic vs Pacific sinking).

\section{f. Water mass transformation estimates}

To understand how variations in the density fluxes over the North Atlantic and polar regions shown in Fig. 10 influence the structure and strength of the overturning circulation we estimate the surface-forced water mass transformation (WMT) based on the approach by Walin (1982). This approach is particularly useful because it provides a way to estimate the rate of deep-water formation based solely on the surface forcing conditions. Walin (1982) showed that the transformation of surface waters by density fluxes between two isopycnals $\sigma$ and $\sigma+\delta \sigma$ (an outcrop region) is equivalent to a diapycnal volume flux across the outcropping isopycnal. Adopting the notation from Brambilla et al. (2008) and Speer and Tziperman (1992) the WMT over a year can be written as

$$
F(\sigma)=\frac{1}{\Delta T \Delta \sigma} \int_{\text {year }} d t \iint_{\text {area }} d A \delta\left(\sigma-\sigma^{\prime}\right) D(x, y, t) .
$$

The term $F(\sigma)$ is the annual mean water mass transformation function equal to the diapycnal volume flux $\left(\mathrm{m}^{3} \mathrm{~s}^{-1}\right)$ over the isopycnal outcrop region with the area $d A$ and $D(x, y, t)$ is the surface density flux sampled at the surface density $\sigma$ by the delta function $\delta$. Negative (positive) values indicate that waters become lighter (denser). The total surface density flux $\left(D ; \mathrm{kg} \mathrm{m}^{-2} \mathrm{~s}^{-1}\right)$ consists of a thermal $\left(D_{\mathrm{HF}}\right)$ and a haline component $\left(D_{\mathrm{FW}}\right)$ :

$$
D(x, y, t)=D_{\mathrm{HF}}+D_{\mathrm{FW}}=-\frac{\alpha Q_{\mathrm{HF}}}{c_{p}}+\beta S Q_{\mathrm{FW}},
$$

where $c_{p}\left(\mathrm{~J} \mathrm{~kg}^{-1} \mathrm{~K}^{-1}\right)$ is the specific heat of seawater, $\alpha$ and $\beta$ are the thermal expansion and haline contraction coefficients respectively (calculated from UNESCO formulas; see McDougall 1987), $Q_{\mathrm{HF}}\left(\mathrm{W} \mathrm{m}^{-2}\right)$ is the net heat flux (positive for ocean heat gain), and $Q_{\mathrm{FW}}$ $\left(\mathrm{kg} \mathrm{m}^{-2} \mathrm{~s}^{-1}\right)$ is the net freshwater flux into the ocean associated with evaporation/precipitation, runoff, and

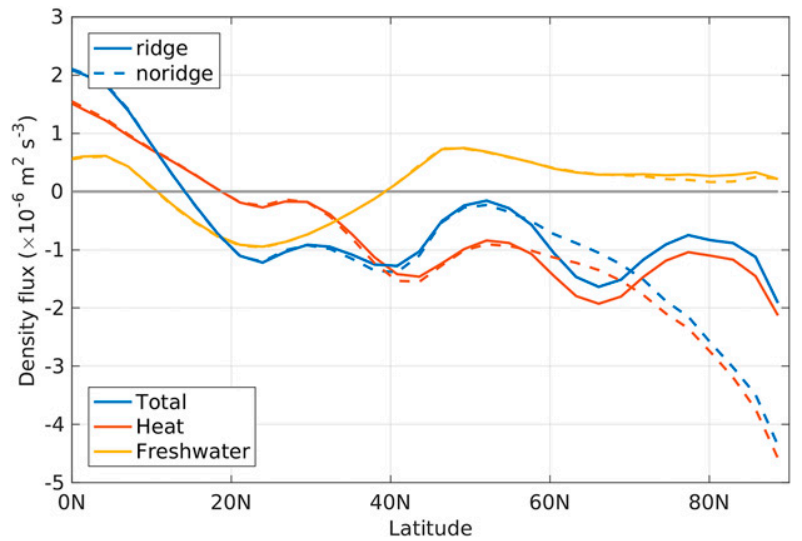

FIG. 10. Zonal mean surface density flux out of the ocean (in $10^{-6} \mathrm{~kg} \mathrm{~m}^{-2} \mathrm{~s}^{-1}$ ) in the North Atlantic for noridge (dashed lines) and ridge (solid lines). The total density flux (blue) is decomposed into contributions from heat (red) and freshwater (yellow) fluxes. Negative values indicate densification (i.e., buoyancy loss). 
melting/freezing of sea ice; finally, $S$ is the sea surface salinity and all variables are functions of space and time.

From the surface forced WMT function it is possible to estimate the water mass formation, which is defined as the divergence of the WMT in Eq. (1):

$$
M d \sigma=-[F(\sigma+d \sigma)-F(\sigma)],
$$

corresponding to the water that accumulates or is lost over a year between two isopycnals $\sigma+d \sigma$ and $\sigma$. The formation per unit density becomes: $[M(\sigma)=d F / d \sigma]$.

In practice we obtain the annual-mean surface forced WMT by calculating the surface density flux in each grid cell for the interval $28.4 \leq \sigma_{2} \leq 36.4 \mathrm{~kg} \mathrm{~m}^{-3}$ with $\Delta \sigma=$ 0.1 and a time step of $\Delta t=5$ for a total of $\Delta T=10$ years taken from the end of the integration. The WMT function is then integrated over the Atlantic basin from $40^{\circ}$ to $90^{\circ} \mathrm{N}$.

The surface forced basin-integrated WMT [Eq. (1)] in the entire North Atlantic region $\left(40^{\circ}-90^{\circ} \mathrm{N}\right)$ is shown in Fig. 11 (upper panel) for the two experiments. The transformation rates for noridge and ridge shows the same general features and compare well with previous studies (e.g., Speer and Tziperman 1992; Brambilla et al. 2008). Negative WMT (associated with a buoyancy gain) is found at low densities in the interval $31.0 \leq \sigma_{2} \leq 33.5$ (i.e., subtropical water), while positive WMT (associated with buoyancy loss from surface cooling) occurs at higher surface densities in the range $33.6 \leq \sigma_{2} \leq 36.4$ (i.e., subpolar water). In noridge, however, there is no transformation for densities greater than $\sigma_{2}>36.1$. Both cases have comparable peak WMT (27.7 and $27.9 \mathrm{~Sv}$ crossing the 35.3 and 35.2 isopycnal for noridge and ridge respectively). This is the magnitude of convection in the Atlantic basin due to surface exchanges, and implies that the production of dense water is virtually constant regardless of the GSR. We note that these values are comparable with the transport in the upper branch of the MOC in Fig. 4 (see also Brambilla et al. 2008).

The spatial distribution of the WMT, however, is quite different in the two configurations. To illustrate this in more detail, the total WMT in the North Atlantic is separated into contributions from the subpolar and polar regions (Fig. 11; middle and lower panel). This reveals a much weaker WMT in the polar basin for ridge ( $7 \mathrm{~Sv}$ vs $15.2 \mathrm{~Sv}$ in noridge), occurring at higher surface densities because the surface waters are colder. It is partly compensated by larger WMT in the subpolar North Atlantic, with a maximum of $26.4 \mathrm{~Sv}$ at the 35.2 isopycnal. This reflects an increase in deep water formation south of the GSR, consistent with the enhanced surface density fluxes and deeper mixed layers (Figs. 9 and 10). Hence, for ridge most of the dense water is
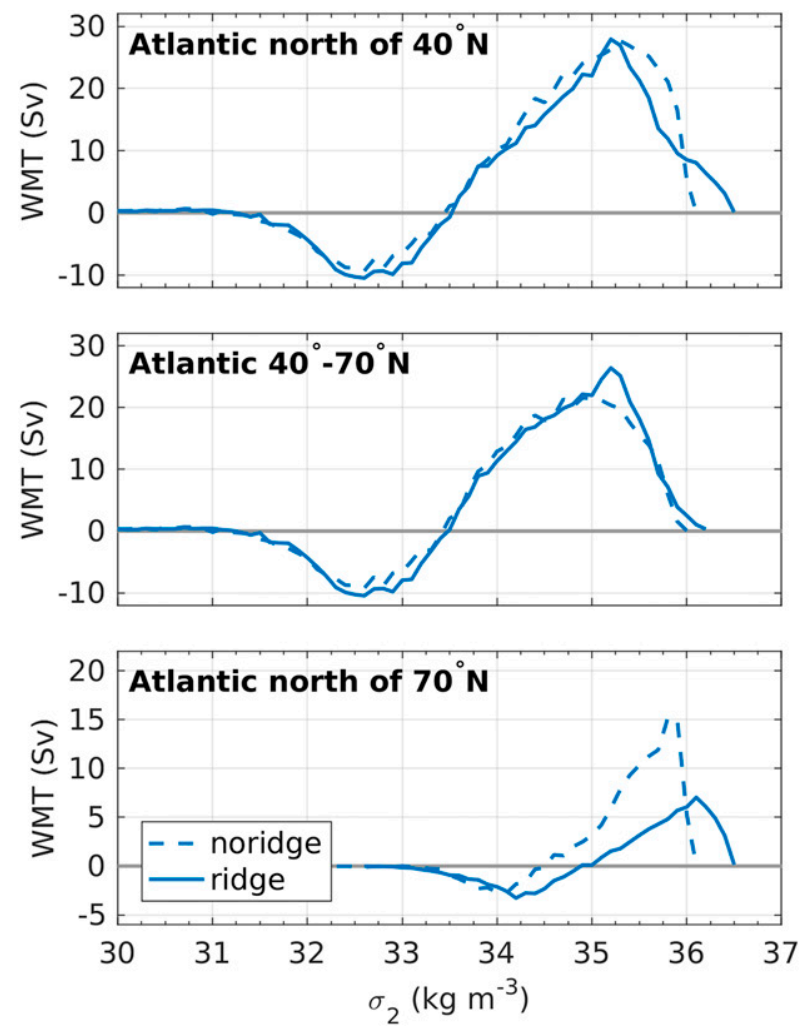

FIG. 11. Annual mean water mass transformation (WMT) function $[F(\sigma)]$ in Sv for noridge (dashed) and ridge (solid). The WMT is integrated over different regions; (top) the entire North Atlantic from $40^{\circ}$ to $90^{\circ} \mathrm{N}$, (middle) subpolar North Atlantic between $40^{\circ}$ and $70^{\circ} \mathrm{N}$, and (bottom) polar basin north of $70^{\circ} \mathrm{N}$. The surface forced WMT is estimated from the spatial integral of the surface density flux $(D)$ over 10 years in the Atlantic basin spanning the density range $\sigma_{2}=28.4-36.4 \mathrm{~kg} \mathrm{~m}^{-3}$ with a density bin width of $\Delta \sigma=0.1$. Here $F(\sigma) \approx 0$ for $\sigma<30$. Negative values imply a WMT to lower density classes (i.e., buoyancy gain) and positive values represents transformation from lower to greater densities (i.e., buoyancy loss).

formed in the subpolar North Atlantic between $40^{\circ}$ and $70^{\circ} \mathrm{N}$ (although approximately $10 \%$ of the total WMT still occurs north of the GSR; i.e., $2.8 \times 10^{6} \mathrm{~kg} \mathrm{~s}^{-1}$ of the net density input, $28 \times 10^{6} \mathrm{~kg} \mathrm{~s}^{-1}$, occurs north of $70^{\circ} \mathrm{N}$ ). In summary, the surface-forced WMT is in good agreement with the overturning transport (i.e., Fig. 4), which both show that the GSR significantly impact the location of deep water formation, but does not affect the total deep water production over the Atlantic basin. As a consequence, the maximum transport by the MOC shows little change.

\section{g. Water mass formation}

The surface-forced water mass formation can be estimated from the divergence of the WMT (Fig. 11), where a negative (positive) slope is associated with water mass formation (destruction) [see Eq. (3)]. We 

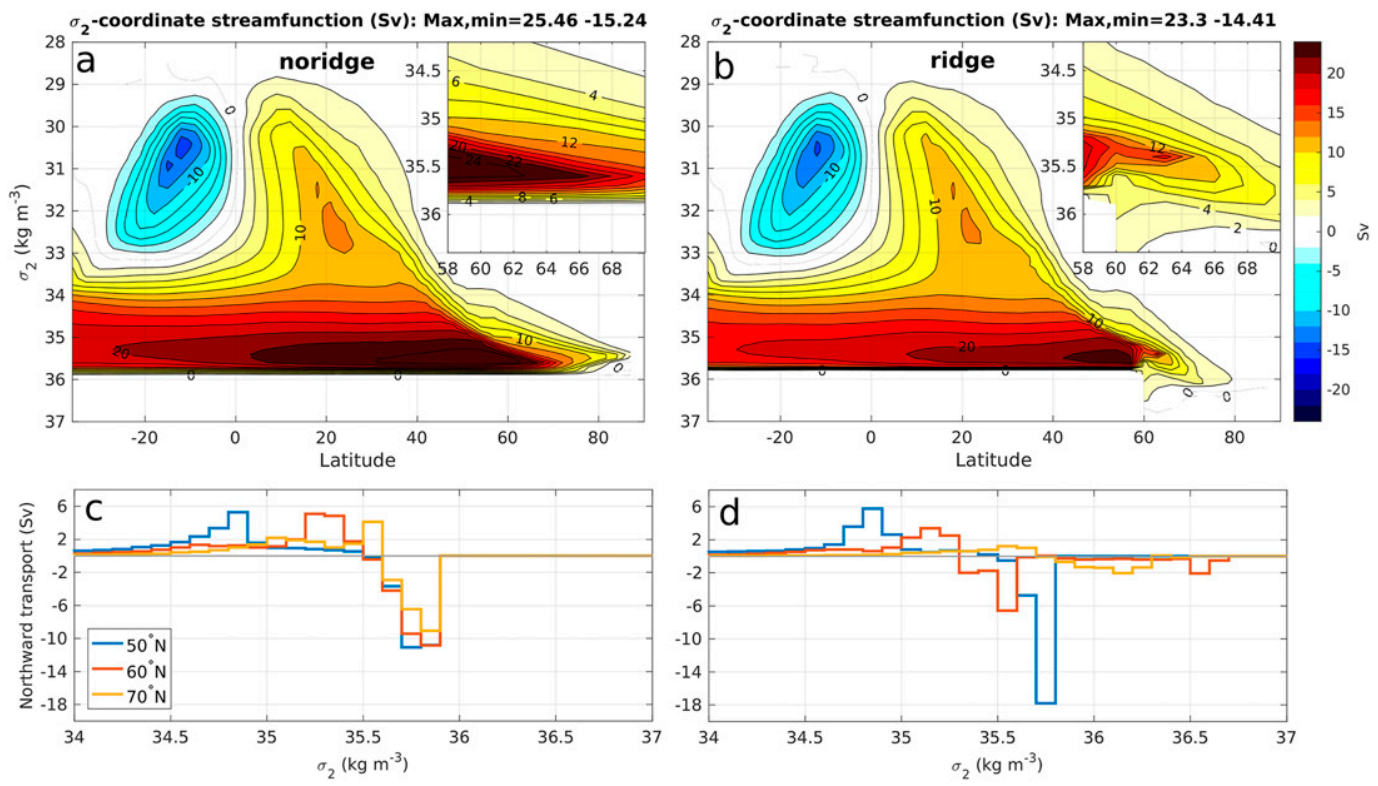

FIG. 12. Meridional overturning circulation streamfunction in latitude-density space $\left(\mathrm{MOC}_{\sigma} ; \mathrm{Sv}\right)$ for (a) noridge and (b) ridge. The density bins are the same as used for the computation of the WMT, with a reference density at $2-\mathrm{km}$ depth. Contour lines are plotted at 2-Sv intervals. The inset in (a) and (b) shows a zoom on the region around the GSR. (c),(d) Mean volume flux (Sv) by $\mathrm{MOC}_{\sigma}$ for noridge and ridge respectively across different latitudes in the Atlantic basin. Positive values indicate northward flow.

compare the implied isopycnal transport from the surface fluxes to the overturning streamfunction in density coordinates (i.e., $\mathrm{MOC}_{\sigma}$ ) in Fig. 12.

The overturning circulation in latitude-density space depicts the gradual densification of surface waters as they move northward. The densification is consistent with a positive WMT (i.e., buoyancy loss) in the subpolar and polar region for densities greater than 33.5 and is similar in strength in both cases. Here the negative slope $(d F / d \sigma<0)$ for $\sigma_{2}>35.3$ in Fig. 11 gives a formation of about $27.6 \mathrm{~Sv}$ for noridge and $23 \mathrm{~Sv}$ in ridge and is balanced by a destruction of intermediate water masses in the range $32.6 \leq \sigma_{2} \leq 35.2$ where $d F / d \sigma>0$. These values are in good agreement with the simulated volume transport by $\mathrm{MOC}_{\sigma}$, which shows a maximum strength of $25.5 \mathrm{~Sv}$ for noridge and 23.3 for ridge, slightly higher than the overturning in latitude-depth space (i.e., $\mathrm{MOC}_{z}$ ). In addition, the overturning maximum is shifted toward the subpolar region $\left(\sim 50^{\circ} \mathrm{N}\right)$, reflecting the transport by the horizontal gyre circulation, which tends to average to zero in latitude-depth space and therefore has little imprint on $\mathrm{MOC}_{z}$.

For noridge $\mathrm{MOC}_{\sigma}$ reveals a relatively low-density (35.6 $\left.\leq \sigma_{2} \leq 35.8\right)$ outflow from the polar basin, indicating that it is formed by local conversion of lighter water originating from the subpolar region. Meanwhile, the water mass characteristics of the southward flow changes very little with latitude, which reflects an interior circulation that is largely adiabatic. In ridge, on the other hand, the southward transport over the GSR at $60^{\circ} \mathrm{N}$ consist of about $6 \mathrm{~Sv}$ of intermediate density waters being recirculated in the SPG and a very dense overflow $\left(\sigma_{2}>36.0\right)$ of $\sim 3 \mathrm{~Sv}$ formed by strong surface cooling in the polar basin. At $50^{\circ} \mathrm{N}$, however, there is no transport of these extreme waters, suggesting that the dense overflow mixes downstream of the GSR to form waters of lighter densities. As a result, there is a sharp peak $(18 \mathrm{~Sv})$ in the southward flux across $50^{\circ} \mathrm{N}$ with density $\sigma_{2}=35.7$.

We note that the estimated WMT by Walin (1982) only consider transformation due to air-sea fluxes, but neglects the WMT associated with mixing processes in the ocean interior and therefore we do not expect a perfect fit between the WMT estimates and $\mathrm{MOC}_{\sigma}$. Vertical mixing is particularly important for the transformation of dense water as it flows over the GSR (Hansen and Østerhus 2000), where it roughly doubles in volume due to turbulent entrainment with ambient waters (Beaird et al. 2013). As a consequence, it is estimated that the overflows supply about one-third of the total volume transport of the AMOC (Hansen et al. 2004). Using a similar entrainment rate implies that the dense overflow from the polar basin (see insert in Fig. 12b) would contribute with about $6 \mathrm{~Sv}$ to the total overturning transport. Still, this is small compared to the air-sea transformation in the subpolar North Atlantic 
$\left(40^{\circ}-70^{\circ} \mathrm{N}\right)$ with an average rate of about $15 \mathrm{~Sv}$, which is the main source of deep water feeding into the MOC (Fig. 11).

\section{h. Sensitivity to the background climate state}

To test the sensitivity of the circulation response to the background climate state, we perform an additional experiment where the GSR is introduced in a colder climate. The main goal is to test if the model responds differently under cold climate conditions (when sea ice is present), where the climate system might be more sensitive to perturbations (e.g., Bitz et al. 2007). This is achieved by reducing the solar constant in noridge by $6 \mathrm{~W} \mathrm{~m}^{-2}$, from the default $S_{0}=1366 \mathrm{~W} \mathrm{~m}^{-2}$ (warm state) to $S_{0}=1360 \mathrm{~W} \mathrm{~m}^{-2}$ (cold state), mimicking a reduction in atmospheric $p \mathrm{CO}_{2}$ (equivalent to slightly less than a factor of 2 reduction).

By lowering the solar constant the climate cools and the model (i.e., cold noridge) reaches a new steady state with a global mean SST of $18.2^{\circ} \mathrm{C}$ (a reduction of $2.5^{\circ} \mathrm{C}$ ). The cooling is amplified at the poles, causing sea ice to form in the Northern Hemisphere (although mainly in the Pacific basin). The MOC in the Atlantic basin is shallower and slightly weaker $\left(20.1 \mathrm{~Sv}\right.$ at $\left.26^{\circ} \mathrm{N}\right)$ compared to the warm case, and a weak AABW cell emerges.

When the GSR is introduced in this colder climate state (i.e., cold ridge), the ocean circulation response is virtually identical to the warm case (Fig. 13): the main downwelling region shifts south of the GSR, the volume transport by the MOC across the GSR is greatly reduced $(\sim 65 \%)$ and the poleward OHT weakens by $29 \%$. Meanwhile, the overall AMOC strength is not affected, which emphasizes the small impact of the GSR on global overturning circulation strength.

The surface climate response is also similar, although the magnitudes of the SST and SSS changes in the Atlantic basin are slightly stronger for the cold case (i.e., the polar basin cools by up to $6^{\circ} \mathrm{C}$ compared to $4^{\circ} \mathrm{C}$ in the warm case). We attribute this to the appearance of a small (seasonal) sea ice cover in the polar basin, which amplifies the cooling and freshening of the high-latitude surface ocean. However, the changes are too small to have an impact on deep water formation, and thus MOC strength and global climate.

\section{Discussion}

\section{a. The relationship between GSR height and AMOC strength}

Earlier proxy-based studies (e.g., Wright and Miller 1996; Davies et al. 2001; Via and Thomas 2006), suggest that changes to the GSR during the Cenozoic had a

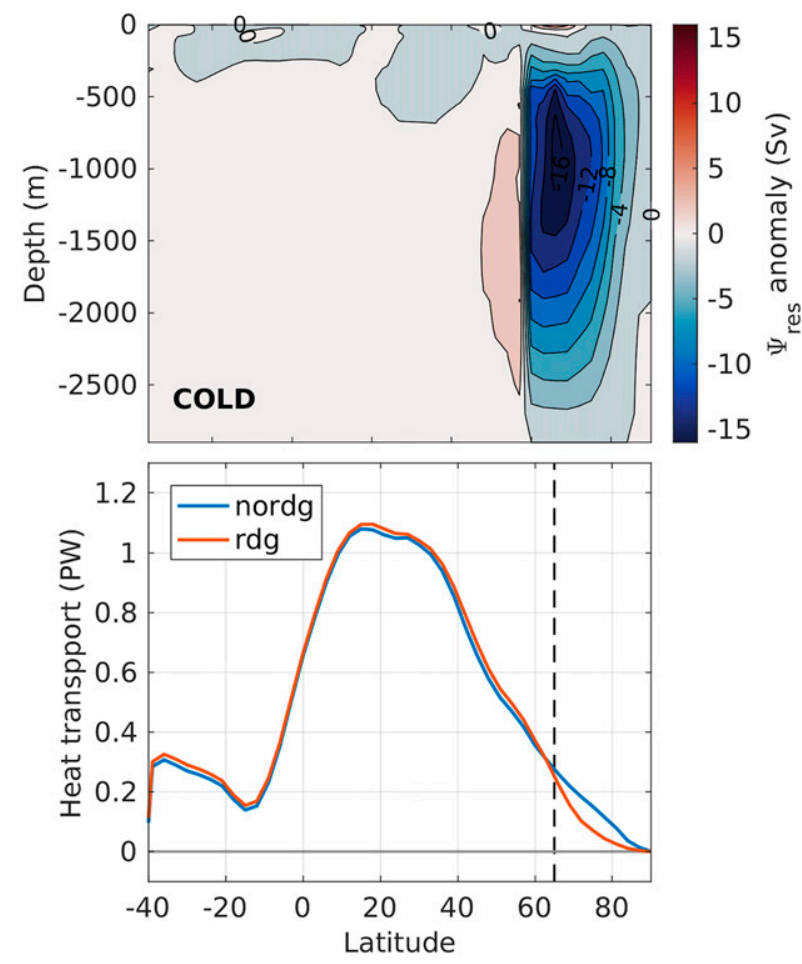

FIG. 13. Meridional overturning streamfunction anomaly (ridge noridge) and ocean heat transport ( $\mathrm{PW}$ ) in the Atlantic basin for the COLD case, where the solar constant is reduced to $1360 \mathrm{~W} \mathrm{~m}^{-2}$.

major impact on the Atlantic overturning circulation and global climate. For example, Abelson et al. (2008) suggested that the global cooling during the EOT, culminating in the glaciation of Antarctica, is linked to the deepening of the GSR, thereby triggering the onset of the AMOC. According to this hypothesis, the AMOC strength is directly correlated to the height of the GSR: deepening of the sill leads to a stronger overflow and higher NADW fluxes, while a shallower sill limits deep water exchange and prevents North Atlantic sinking. Similarly, our results do show a connection between variations in sill depth and deep-water production in the Nordic seas: the average production rate of dense water north of the GSR decreases from $\sim 7$ to $\sim 3$ Sv between noridge and ridge. This leads to a weaker (but denser) overflow across the GSR, consistent with other paleoclimate model simulations (e.g., Robinson et al. 2011; Hill 2015). However, the total amount of deep water formed is unchanged as a result of changes south of the GSR (Fig. 11), and the AMOC at $26^{\circ} \mathrm{N}$ decreases by less than $2 \mathrm{~Sv}$. This implies that variations in the strength of the Nordic seas overflow do not necessarily translate into large changes in the AMOC, as suggested by modern observational studies (e.g., Olsen et al. 2008; Tett et al. 2014; Moffa-Sanchez et al. 2015). 
On the other hand, the AMOC might be more strongly affected if the GSR is significantly shallower, by restricting the North Atlantic-Arctic water exchange. To test the effect of a shallower GSR on the AMOC response we performed an experiment comparing the ridge configuration (with a sill depth of $500 \mathrm{~m}$ ) to a shallow GSR of $\sim 100 \mathrm{~m}$. This experiment was run for 200 years (see the online supplemental material). With a shallower GSR we found that the inflow of warm and salty Atlantic water to the polar basin is drastically reduced and thus prevents deep water from forming in the polar basin. Consequently, the maximum AMOC at $26^{\circ} \mathrm{N}$ decreases from $22.1 \mathrm{~Sv}$ in ridge to $18.5 \mathrm{~Sv}$ in ridge100. This weakening of the AMOC (by $3.6 \mathrm{~Sv}$ ) is consistent with an absence of dense overflow water formed in the polar basin (roughly $3 \mathrm{~Sv}$ in ridge). Nevertheless, despite there being virtually no overflow, the AMOC remains relatively strong as a result of active deep-water formation south of the GSR. These results support our conclusion that GSR sill-depth changes are not likely the primary driver of AMOC variations and changes in global climate during the Cenozoic (see also Hutchinson et al. 2019).

\section{b. The impact of dense overflows}

One explanation for the weak MOC response to changes in the sill depth is that our model does not realistically simulate the GSR overflow. In reality, the dense-water overflow occurs in narrow and deep channels, through the Denmark Strait $(\sim 840 \mathrm{~m})$ and Faroe Bank Channel $(\sim 630 \mathrm{~m})$, which are poorly represented in most present-day ocean models (Heuzé and Årthun 2019). Using a coarse-resolution ocean model, Roberts and Wood (1997) showed that even small topographic changes in these deep channels can have a large impact on overflow transports and AMOC strength. Therefore, we might expect that the absence of such channels in our idealized setup results in too weak overflow transports. On the other hand, the overflow response to topographic changes can be sensitive to the model's vertical resolution and coordinate system (Griffies et al. 2000; Riemenschneider and Legg 2007). Hence, the larger number of vertical levels in our model [30 levels compared to 20 in Roberts and Wood (1997)] allows for a substantial overflow transport, evident in Fig. 12, despite the lack of deep overflow channels. We note, however, that the simulated overflow of $3 \mathrm{~Sv}$ when the GSR is present is only about half of the observed estimates (Hansen and Østerhus 2000). This is probably a combination of the idealized representation of the GSR bathymetry and low horizontal resolution. Admittedly, at coarse resolution $\left(2.8^{\circ}\right)$ we may not fully resolve the narrow boundary currents at high latitudes, which could affect the poleward penetration of Atlantic water across the GSR (Heuzé and Årthun 2019; Spence et al. 2008). As a consequence, we may underestimate the amount of deep water formed north of the GSR.

From Fig. 12 we see that no dense water mass is found south of the GSR, which is most likely due to strong vertical mixing at the GSR as our model lacks an implicit overflow parameterization. This is a common issue in coarse-resolution models, causing excessive convective entrainment and deep waters that are too light (Willebrand et al. 2001; Ezer and Mellor 2004; Danabasoglu et al. 2010; Yeager and Danabasoglu 2012). Hence, the representation of overflow water may have a significant impact on the MOC volume transport. By implementing an overflow parameterization in a fully coupled climate model, Yeager and Danabasoglu (2012) found that the AMOC increases by $4-6 \mathrm{~Sv}$ in the subpolar North Atlantic between $40^{\circ}$ and $60^{\circ} \mathrm{N}$, while the maximum AMOC transport at $37^{\circ} \mathrm{N}$ decreases. Meanwhile, other studies using a parameterization based on hydraulic constraints (e.g., Legutke and Maier-Reimer 2002; Kösters et al. 2005; Born et al. 2009) only show a small (less than 2 Sv) effect of Nordic seas overflows on North Atlantic overturning strength. Despite the weak response in overturning, Kösters et al. (2005) show that the GSR overflow has a large impact on North Atlantic climate, by increasing the northward ocean heat transport and warming the Nordic seas. In our simulations as well, the overflows play a relatively small role in determining the strength of the Atlantic overturning circulation. Instead, we argue that the overturning circulation in our model is more sensitive to changes in surface buoyancy fluxes over the North Atlantic region, setting the location and strength of NADW formation. This is further supported by model simulations from Stärz et al. (2017), who show that a substantial NADW flow can exist, even for extremely shallow sill depths $(<50 \mathrm{~m})$ with virtually no overflow. Alternatively, other mechanisms are likely to influence the strength of the AMOC [see review by Kuhlbrodt et al. (2007)], for example: wind-driven upwelling of NADW in the Southern Ocean (Toggweiler and Samuels 1995; Marshall and Speer 2012). As such, the fact that surface winds and upwelling in the Southern Ocean remain constant in our model simulation (not shown) may contribute to the relatively stable AMOC.

\section{c. Implications for paleoclimate}

The prevailing explanation for past changes in North Atlantic and high-latitude climate involves changes in the AMOC and northward OHT ranging from relatively abrupt centennial-to-millennial time scales (e.g., Broecker et al. 1985; Rahmstorf 2002; Clark et al. 2002; Lynch-Stieglitz 2017) to very slow multimillion year 
time scales associated with bathymetry changes and plate tectonics (e.g., Wright and Miller 1996; Davies et al. 2001; Via and Thomas 2006). Such changes in past climate are inferred from indirect measurements (i.e., proxies) that record a local climate signal, reflecting past changes in surface climate conditions, circulation strength, or deep water properties, but are often interpreted as representing changes in large-scale ocean circulation. For example, it is generally assumed that the high SSTs found in the North Atlantic and Arctic Ocean during the MPWP are evidence for a stronger AMOC compared to the modern period, driving a stronger OHT to the high latitudes (Dowsett et al. 1992; Raymo et al. 1996). In this view, the strength of the overturning circulation is inferred from the SST pattern recorded in the proxies, thus assuming that global AMOC strength is directly correlated with the poleward heat transport and surface temperature at high latitudes.

In contrast to this view, our simulations illustrate that large changes in high-latitude surface climate can occur without invoking changes in large-scale ocean circulation. A central element to this is the disconnect between the AMOC and high-latitude OHT, which has been highlighted by several studies (e.g., Spall 2001; Wunsch 2006; Ferrari and Ferreira 2011; Zhang et al. 2013; Nummelin et al. 2017; Li and Born 2019; Årthun et al. 2019) and questions the traditional view that the AMOC is the main driver of changes in high-latitude climate. This has implications for the interpretation of paleoproxy records; while proxies could indicate a large change in high-latitude surface climate, water mass properties, or ventilation, they do not necessarily imply a large change in the AMOC on a global scale. For example, several models have shown that OHT across the GSR may actually increase despite an AMOC slowdown (e.g., Zhang et al. 2013; Årthun et al. 2019) as a result of changes in the horizontal circulation. Similarly, our results emphasize the importance of the shallow overturning by the subpolar gyre in controlling high-latitude climate. In fact, the gyre maintains a substantial heat transport to the polar regions, despite a weakening of the heat transport by the deep MOC. Hence, an improved understanding of the processes affecting the horizontal gyre circulation is critical for understanding past climate variability at high northern latitudes [see also Li and Born (2019) for a discussion].

\section{Conclusions}

Using a coupled atmosphere-ocean-sea ice model with idealized Earth-like geometry, we explore the role of the Greenland-Scotland Ridge (GSR) in shaping the modern ocean circulation and its control on deep-water formation, ocean heat transport, and high-latitude surface climate.

When the GSR is absent, deep-water formation occurs near the North Pole in the Atlantic basin and a deep meridional overturning circulation (MOC) extends well into the high latitudes. This is associated with a strong northward ocean heat transport that warms the high latitudes and weakens the equator-to-pole SST gradient.

By introducing an idealized GSR, the main location of deep-water formation shifts southward, causing the structure of the overturning circulation at subpolar and high latitudes to change dramatically. The meridional volume transport by the MOC across the GSR decreases by more than $64 \%$ and the poleward ocean heat transport is reduced by $\sim 30 \%$. However, the overall strength of the MOC south of the GSR remains largely unaffected and the AMOC at $26^{\circ} \mathrm{N}$ decreases by only $2 \mathrm{~Sv}$ (a 5\% decrease). This relatively weak response is due to enhanced deep water production south of GSR, as a result of surface buoyancy changes. This suggests that AMOC strength may be decoupled from the flow across the GSR. As the subpolar North Atlantic (south of the GSR) becomes the main region of deep water formation and the polar basin becomes less ventilated, the overall rate of water mass transformation in the Atlantic remains unchanged, while a modern-type bidirectional flow regime is established with warm inflow at the surface and a cold, dense overflow above the sill.

As a result, the water column north of the GSR cools and freshens, and precipitation accumulates because of reduced exchange, while the subpolar region (south of the GSR) becomes warmer and saltier. The surface temperature and salinity in the polar basin decreases, which leads to a weakening of the equator-to-pole temperature gradient in the Atlantic basin. These results are consistent with paleoproxies and previous modeling efforts that indicate that Arctic surface climate is sensitive to changes in the height of the GSR (Dowsett et al. 2010; Robinson et al. 2011; BrighamGrette et al. 2013; Stärz et al. 2017), and is likely due to reductions in the northward ocean heat transport.

The smaller sensitivity of the OHT across $70^{\circ} \mathrm{N}$, compared to the MOC, shows that the horizontal circulation by the subpolar gyre maintains a significant transport of heat to the high latitudes. Our results emphasize that the shallow horizontal circulation is critical for controlling mid-to-high-latitude OHT, as shown by previous studies (e.g., Ferrari and Ferreira 2011; Li and Born 2019). However, despite relatively large changes in ocean circulation, heat transport, and surface climate at high latitudes, the large-scale global climate shows no change. This result is independent of the background climate state in which the GSR is added. Contrary to 
previous suggestions (Wright and Miller 1996; Abelson et al. 2008), our results suggest that variations in GSR height alone cannot explain dramatic planetary climate change. At least, further amplification by internal feedbacks (e.g., $\mathrm{CO}_{2}$ ) needs to be invoked.

Our results have potential implications for the interpretation of paleoproxies by highlighting a potential disconnect between the AMOC and high-latitude surface climate response, which is often inferred in paleoclimate studies (e.g., Dowsett et al. 1992; Raymo et al. 1996; Rahmstorf 2002). In contrast, we show that large changes in water mass properties and surface climate at high latitudes can be simulated without large AMOC changes on hemispheric and global scales. Therefore we propose that caution be taken when inferring a direct relationship between indirect and nonlocal measurements of overturning strength, high-latitude SST/SSS changes recorded in proxies, and large-scale climate.

Acknowledgments. The authors thank the two anonymous reviewers and the editor of this paper for the constructive comments, which helped improve the manuscript significantly. The research leading to these results has received funding from the European Research Council under the European Community's Seventh Framework Programme (FP7/2007-2013)/ERC grant agreement 610055 as part of the ice2ice project. The research was supported by the Centre for Climate Dynamics at the Bjerknes Centre.

\section{REFERENCES}

Abelson, M., and J. Erez, 2017: The onset of modern-like Atlantic meridional overturning circulation at the Eocene-Oligocene transition: Evidence, causes, and possible implications for global cooling. Geochem. Geophys. Geosyst., 18, 2177-2199, https://doi.org/10.1002/2017GC006826.

_ , A. Agnon, and A. Almogi-Labin, 2008: Indications for control of the Iceland plume on the Eocene-Oligocene "greenhouse-icehouse" climate transition. Earth Planet. Sci. Lett., 265, 33-48, https://doi.org/10.1016/j.epsl.2007.09.021.

Adcroft, A., and J. M. Campin, 2004: Rescaled height coordinates for accurate representation of free-surface flows in ocean circulation models. Ocean Modell., 7, 269-284, https://doi.org/ 10.1016/j.ocemod.2003.09.003.

Årthun, M., T. Eldevik, and L. H. Smedsrud, 2019: The role of Atlantic heat transport in future Arctic winter sea ice loss. J. Climate, 32, 3327-3341, https://doi.org/10.1175/JCLI-D-180750.1.

Barker, P. F., and J. Burrell, 1977: The opening of Drake Passage. Mar. Geol., 25, 15-34, https://doi.org/10.1016/0025-3227(77) 90045-7.

Beaird, N. L., P. B. Rhines, C. C. Eriksen, N. L. Beaird, P. B. Rhines, and C. C. Eriksen, 2013: Overflow waters at the Iceland-Faroe Ridge observed in multiyear Seaglider surveys. J. Phys. Oceanogr., 43, 2334-2351, https://doi.org/10.1175/ JPO-D-13-029.1.
Bitz, C. M., J. C. Chiang, W. Cheng, and J. J. Barsugli, 2007: Rates of thermohaline recovery from freshwater pulses in modern, Last Glacial Maximum, and greenhouse warming climates. Geophys. Res. Lett., 34, L07708, https://doi.org/10.1029/ 2006 GL029237.

Born, A., A. Levermann, and J. Mignot, 2009: Sensitivity of the Atlantic Ocean circulation to a hydraulic overflow parameterisation in a coarse resolution model: Response of the subpolar gyre. Ocean Modell., 27, 130-142, https://doi.org/ 10.1016/j.ocemod.2008.11.006.

Bower, A., and Coauthors, 2019: Lagrangian views of the pathways of the Atlantic meridional overturning circulation. J. Geophys. Res. Oceans, 124, 5313-5335, https://doi.org/ 10.1029/2019JC015014.

Brambilla, E., L. D. Talley, and P. E. Robbins, 2008: Subpolar mode water in the northeastern Atlantic: 2. Origin and transformation. J. Geophys. Res., 113, C04026, https://doi.org/ 10.1029/2006JC004063.

Brigham-Grette, J., and Coauthors, 2013: Pliocene warmth, polar amplification, and stepped Pleistocene cooling recorded in NE Arctic Russia. Science, 340, 1421-1427, https://doi.org/10.1126/ science.1233137.

Broecker, W. S., D. M. Peteet, and D. Rind, 1985: Does the oceanatmosphere system have more than one stable mode of operation? Nature, 315, 21-26, https://doi.org/10.1038/315021a0.

Clark, P. U., N. G. Pisias, T. F. Stocker, and A. J. Weaver, 2002: The role of the thermohaline circulation in abrupt climate change. Nature, 415, 863-869, https://doi.org/10.1038/415863a.

Danabasoglu, G., W. G. Large, and B. P. Briegleb, 2010: Climate impacts of parameterized Nordic Sea overflows. J. Geophys. Res., 115, C11005, https://doi.org/10.1029/2010JC006243.

Davies, R., J. Cartwright, J. Pike, and C. Line, 2001: Early Oligocene initiation of North Atlantic deep water formation. Nature, 410, 917-920, https://doi.org/10.1038/35073551.

DeConto, R. M., and D. Pollard, 2003: Rapid Cenozoic glaciation of Antarctica induced by declining atmospheric $\mathrm{CO}_{2}$. Nature, 421, 245-249, https://doi.org/10.1038/nature01290.

de Lavergne, C., G. Madec, F. Roquet, R. M. Holmes, and T. J. McDougall, 2017: Abyssal ocean overturning shaped by seafloor distribution. Nature, 551, 181-186, https://doi.org/ 10.1038/nature24472.

Dowsett, H. J., T. M. Cronin, R. Z. Poore, R. S. Thompson, R. C. Whatley, and A. M. Wood, 1992: Micropaleontological evidence for increased meridional heat transport in the North Atlantic Ocean during the Pliocene. Science, 258, 1133-1135, https://doi.org/10.1126/science.258.5085.1133.

— M. M. Robinson, and K. M. Foley, 2009: Pliocene threedimensional global ocean temperature reconstruction. Climate Past, 5, 769-783, https://doi.org/10.5194/cp-5-769-2009.

— , and Coauthors, 2010: The PRISM3D paleoenvironmental reconstruction. Stratigraphy, 7, 123-139.

Enderton, D., and J. Marshall, 2009: Explorations of atmosphereocean-ice climates on an aquaplanet and their meridional energy transports. J. Atmos. Sci., 66, 1593-1611, https:// doi.org/10.1175/2008JAS2680.1.

Ezer, T., and G. L. Mellor, 2004: A generalized coordinate ocean model and a comparison of the bottom boundary layer dynamics in terrain-following and in $z$-level grids. Ocean Modell., 6, 379-403, https://doi.org/10.1016/S1463-5003(03) 00026-X

Ferrari, R., and D. Ferreira, 2011: What processes drive the ocean heat transport? Ocean Modell., 38, 171-186, https://doi.org/ 10.1016/j.ocemod.2011.02.013. 
Ferreira, D., J. Marshall, and J. M. Campin, 2010: Localization of deep water formation: Role of atmospheric moisture transport and geometrical constraints on ocean circulation. J. Climate, 23, 1456-1476, https://doi.org/10.1175/2009JCLI3197.1.

,$- \ldots$, and B. Rose, 2011: Climate determinism revisited: Multiple equilibria in a complex climate model. J. Climate, $\mathbf{2 4 ,}$ 992-1012, https://doi.org/10.1175/2010JCLI3580.1.

_ , and Coauthors, 2018: Atlantic-Pacific asymmetry in deep water formation. Annu. Rev. Earth Planet. Sci., 46, 327-352, https://doi.org/10.1146/annurev-earth-082517-010045.

Gent, P. R., and J. C. McWilliams, 1990: Isopycnal mixing in ocean circulation models. J. Phys. Oceanogr., 20, 150-155, https://doi.org/10.1175/1520-0485(1990)020<0150:IMIOCM> 2.0.CO;2.

Gille, S., and S. L. Smith, 2003: Bathymetry and ocean circulation. Charting the Secret World of the Ocean Floor: The GEBCO Project 1903-2003, 9 pp., https://www.gebco.net/about_us/ presentations_and_publications/documents/cen_conf_abstract_ gille.pdf.

Griffies, S. M., and Coauthors, 2000: Developments in ocean climate modelling. Ocean Modell., 2, 123-192, https://doi.org/ 10.1016/S1463-5003(00)00014-7.

Hansen, B., and S. Østerhus, 2000: North Atlantic-Nordic seas exchanges. Prog. Oceanogr., 45, 109-208, https://doi.org/10.1016/ S0079-6611(99)00052-X.

—_, and —_, 2007: Faroe Bank channel overflow 1995-2005. Prog. Oceanogr., 75, 817-856, https://doi.org/10.1016/ j.pocean.2007.09.004

,$- \ldots$, D. Quadfasel, and W. Turrell, 2004: Already the day after tomorrow? Science, 305, 953-954, https://doi.org/10.1126/ science. 1100085.

Haug, G. H., and R. Tiedemann, 1998: Effect of the formation of the isthmus of Panama on Atlantic Ocean thermohaline circulation. Nature, 393, 673-676, https://doi.org/10.1038/31447.

Heuzé, C., and M. Årthun, 2019: The Atlantic inflow across the Greenland-Scotland ridge in global climate models (CMIP5). Elementa Sci. Anthropocene, 7, 16, https://doi.org/10.1525/ elementa.354.

Hill, D. J., 2015: The non-analogue nature of Pliocene temperature gradients. Earth Planet. Sci. Lett., 425, 232-241, https://doi.org/ 10.1016/j.epsl.2015.05.044.

Hutchinson, D. K., H. K. Coxall, M. O'Regan, J. Nilsson, R. Caballero, and A. M. de Boer, 2019: Arctic closure as a trigger for Atlantic overturning at the Eocene-Oligocene transition. Nat. Commun., 10, 3797, https://doi.org/10.1038/ s41467-019-11828-z.

Iovino, D., F. Straneo, and M. A. Spall, 2008: On the effect of a sill on dense water formation in a marginal sea. J. Mar. Res., 66, 325-345, https://doi.org/10.1357/002224008786176016.

Kösters, F., R. H. Käse, A. Schmittner, and P. Herrmann, 2005: The effect of Denmark Strait overflow on the Atlantic meridional overturning circulation. Geophys. Res. Lett., 32, L04602, https://doi.org/10.1029/2004GL022112.

Kuhlbrodt, T., A. Griesel, M. Montoya, A. Levermann, M. Hofmann, and S. Rahmstorf, 2007: On the driving processes of the Atlantic meridional overturning circulation. Rev. Geophys., 45, RG2001, https://doi.org/10.1029/2004RG000166.

Large, W. G., J. C. McWilliams, and S. C. Doney, 1994: Oceanic vertical mixing: A review and a model with a nonlocal boundary layer parameterization. Rev. Geophys., 32, 363-403, https://doi.org/10.1029/94RG01872.

Legutke, S., and E. Maier-Reimer, 2002: The impact of a downslope water-transport parametrization in a global ocean general circulation model. Climate Dyn., 18, 611-623, https://doi.org/ 10.1007/s00382-001-0202-z.

Li, C., and A. Born, 2019: Coupled atmosphere-ice-ocean dynamics in Dansgaard-Oeschger events. Quat. Sci. Rev., 203 1-20, https://doi.org/10.1016/j.quascirev.2018.10.031.

Lozier, M. S., and Coauthors, 2017: Overturning in the subpolar North Atlantic program: A new international ocean observing system. Bull. Amer. Meteor. Soc., 98, 737-752, https://doi.org/ 10.1175/BAMS-D-16-0057.1.

Lynch-Stieglitz, J., 2017: The Atlantic meridional overturning circulation and abrupt climate change. Annu. Rev. Mar. Sci., 9, 83-104, https://doi.org/10.1146/annurev-marine-010816-060415.

Marshall, J., and K. Speer, 2012: Closure of the meridional overturning circulation through Southern Ocean upwelling. Nat. Geosci., 5, 171-180, https://doi.org/10.1038/ngeo1391.

— A. Adcroft, C. Hill, L. Perelman, and C. Heisey, 1997: A finite-volume, incompressible Navier Stokes model for studies of the ocean on parallel computers. J. Geophys. Res., 102, 5753-5766, https://doi.org/10.1029/96JC02775.

— D. Ferreira, J.-M. Campin, and D. Enderton, 2007: Mean climate and variability of the atmosphere and ocean on an aquaplanet. J. Atmos. Sci., 64, 4270-4286, https://doi.org/ 10.1175/2007JAS2226.1.

McDougall, T. J., 1987: Neutral surfaces. J. Phys. Oceanogr., 17, 1950-1964, https://doi.org/10.1175/1520-0485(1987)017<1950: $\mathrm{NS}>2.0 . \mathrm{CO} ; 2$.

Medhaug, I., H. R. Langehaug, T. Eldevik, T. Furevik, and M. Bentsen, 2012: Mechanisms for decadal scale variability in a simulated Atlantic meridional overturning circulation. Climate Dyn., 39, 77-93, https://doi.org/10.1007/s00382-011-1124-z.

Moffa-Sanchez, P., I. R. Hall, D. J. Thornalley, S. Barker, and C. Stewart, 2015: Changes in the strength of the Nordic Seas Overflows over the past 3000 years. Quat. Sci. Rev., 123, 134143, https://doi.org/10.1016/j.quascirev.2015.06.007.

Molteni, F., 2003: Atmospheric simulations using a GCM with simplified physical parametrizations. I: Model climatology and variability in multi-decadal experiments. Climate Dyn., 20, 175-191, https://doi.org/10.1007/s00382-002-0268-2.

Nummelin, A., C. Li, and P. J. Hezel, 2017: Connecting ocean heat transport changes from the midlatitudes to the Arctic Ocean. Geophys. Res. Lett., 44, 1899-1908, https://doi.org/10.1002/ 2016 GL071333.

Olsen, S. M., B. Hansen, D. Quadfasel, and S. Østerhus, 2008: Observed and modelled stability of overflow across the Greenland-Scotland ridge. Nature, 455, 519-522, https://doi.org/ 10.1038/nature07302.

Østerhus, S., W. R. Turrell, S. Jónsson, and B. Hansen, 2005: Measured volume, heat, and salt fluxes from the Atlantic to the Arctic Mediterranean. Geophys. Res. Lett., 32, L07603, https://doi.org/10.1029/2004GL022188.

Polzin, K. L., J. M. Toole, J. R. Ledwell, and R. W. Schmitt, 1997: Spatial variability of turbulent mixing in the abyssal ocean. Science, 276, 93-96, https://doi.org/10.1126/science.276.5309.93.

Rahmstorf, S., 2002: Ocean circulation and climate during the past 120,000 years. Nature, 419, 207-214, https://doi.org/10.1038/ nature 01090 .

Raymo, M. E., B. Grant, M. Horowitz, and G. H. Rau, 1996: MidPliocene warmth: Stronger greenhouse and stronger conveyor. Mar. Micropaleontol., 27, 313-326, https://doi.org/10.1016/ 0377-8398(95)00048-8.

Redi, M. H., 1982: Oceanic isopycnal mixing by coordinate rotation. J. Phys. Oceanogr., 12, 1154-1158, https://doi.org/10.1175/ 1520-0485(1982)012<1154:OIMBCR > 2.0.CO;2. 
Riemenschneider, U., and S. Legg, 2007: Regional simulations of the Faroe Bank Channel overflow in a level model. Ocean Modell., 17, 93-122, https://doi.org/10.1016/j.ocemod.2007.01.003.

Roberts, M. J., and R. A. Wood, 1997: Topographic sensitivity studies with a Bryan-Cox-type ocean model. J. Phys. Oceanogr., 27, 823-836, https://doi.org/10.1175/1520-0485(1997)027<0823: TSSWAB $>2.0 . \mathrm{CO} ; 2$.

Robinson, M. M., P. J. Valdes, A. M. Haywood, H. J. Dowsett, D. J. Hill, and S. M. Jones, 2011: Bathymetric controls on Pliocene North Atlantic and Arctic sea surface temperature and deepwater production. Palaeogeogr. Palaeoclimatol. Palaeoecol. 309, 92-97, https://doi.org/10.1016/j.palaeo.2011.01.004.

Rose, B. E., D. Ferreira, and J. Marshall, 2013: The role of oceans and sea ice in abrupt transitions between multiple climate states. J. Climate, 26, 2862-2879, https://doi.org/10.1175/JCLI-D-12-00175.1.

Sévellec, F., A. V. Fedorov, and W. Liu, 2017: Arctic sea-ice decline weakens the Atlantic meridional overturning circulation. Nat. Climate Change, 7, 604-610, https://doi.org/10.1038/nclimate3353.

Spall, M. A., 2001: Where does dense water sink? A subpolar gyre example. J. Phys. Oceanogr., 31, 810-826, https://doi.org/ 10.1175/1520-0485(2001)031<0810:WDDWSA > 2.0.CO;2.

Speer, K., and E. Tziperman, 1992: Rates of water mass formation in the North Atlantic Ocean. J. Phys. Oceanogr., 22, 93-104, https://doi.org/10.1175/1520-0485(1992)022<0093:ROWMFI> 2.0.CO;2.

Spence, J. P., M. Eby, A. J. Weaver, J. P. Spence, M. Eby, and A. J. Weaver, 2008: The sensitivity of the Atlantic meridional overturning circulation to freshwater forcing at eddy-permitting resolutions. J. Climate, 21, 2697-2710, https://doi.org/10.1175/2007JCLI2103.1.

Stärz, M., W. Jokat, G. Knorr, and G. Lohmann, 2017: Threshold in North Atlantic-Arctic Ocean circulation controlled by the subsidence of the Greenland-Scotland Ridge. Nat. Commun., $\mathbf{8}, 15681$, https://doi.org/10.1038/ncomms15681.

Tett, S. F. B., T. J. Sherwin, A. Shravat, O. Browne, S. F. B. Tett, T. J. Sherwin, A. Shravat, and O. Browne, 2014: How much has the North Atlantic Ocean overturning circulation changed in the last 50 years? J. Climate, 27, 6325-6342, https://doi.org/ 10.1175/JCLI-D-12-00095.1.

Toggweiler, J. R., and B. Samuels, 1995: Effect of Drake Passage on the global thermohaline circulation. Deep-Sea Res. I, $\mathbf{4 2}$, 477-500, https://doi.org/10.1016/0967-0637(95)00012-U.
- , and H. Bjornsson, 2000: Drake Passage and palaeoclimate. J. Quat. Sci., 15, 319-328, https://doi.org/10.1002/ 1099-1417(200005)15:4<319::AID-JQS545>3.0.CO;2-C.

Trenberth, K. E., and J. M. Caron, 2001: Estimates of meridional atmosphere and ocean heat transports. J. Climate, 14, 3433-3443, https://doi.org/10.1175/1520-0442(2001)014<3433:EOMAAO > 2.0.CO;2.

Uenzelmann-Neben, G., and J. Gruetzner, 2018: Chronology of Greenland Scotland Ridge overflow: What do we really know? Mar. Geol., 406, 109-118, https://doi.org/10.1016/ j.margeo.2018.09.008.

Via, R. K., and D. J. Thomas, 2006: Evolution of Atlantic thermohaline circulation: Early Oligocene onset of deep-water production in the North Atlantic. Geology, 34, 441-444, https://doi.org/10.1130/G22545.1.

Walin, G., 1982: On the relation between sea-surface heat flow and thermal circulation in the ocean. Tellus, 34, 187-195, https:// doi.org/10.3402/tellusa.v34i2.10801.

Willebrand, J., and Coauthors, 2001: Circulation characteristics in three eddy-permitting models of the North Atlantic. Prog. Oceanogr., 48, 123-161, https://doi.org/ 10.1016/S0079-6611(01)00003-9.

Winton, M., 2000: A reformulated three-layer sea ice model. J. Atmos. Oceanic Technol., 17, 525-531, https://doi.org/ 10.1175/1520-0426(2000)017<0525:ARTLSI >2.0.CO;2.

Wright, J. D., and K. G. Miller, 1996: Control of North Atlantic deep water circulation by the Greenland-Scotland Ridge. Paleoceanography, 11, 157-170, https://doi.org/10.1029/ 95PA03696.

Wunsch, C., 2005: The total meridional heat flux and its oceanic and atmospheric partition. J. Climate, 18, 4374-4380, https:// doi.org/10.1175/JCLI3539.1.

, 2006: Abrupt climate change: An alternative view. Quat. Res., 65, 191-203, https://doi.org/10.1016/j.yqres.2005.10.006.

Yeager, S., and G. Danabasoglu, 2012: Sensitivity of Atlantic meridional overturning circulation variability to parameterized Nordic Sea overflows in CCSM4. J. Climate, 25, 2077-2103, https://doi.org/10.1175/JCLI-D-11-00149.1.

Zhang, Z. S., and Coauthors, 2013: Mid-Pliocene Atlantic meridional overturning circulation not unlike modern. Climate Past, 9, 1495-1504, https://doi.org/10.5194/cp-9-1495-2013. 